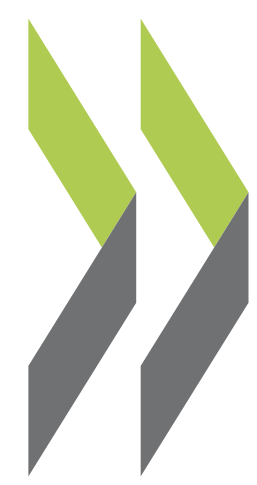

OECD Economics Department Working Papers No. 1586

\title{
What drives \\ the performance of Swedish lower secondary schools?
}

\section{Christophe André,}

\author{
Jon Pareliussen,
}

Hyunjeong Hwang 


\section{WHAT DRIVES THE PERFORMANCE OF SWEDISH LOWER SECONDARY SCHOOLS?}

ECONOMICS DEPARTMENT WORKING PAPERS No. 1586

\section{By Christophe André, Jon Pareliussen and Hyunjeong Hwang}

OECD Working Papers should not be reported as representing the official views of the OECD or of its member countries. The opinions expressed and arguments employed are those of the author(s).

Authorised for publication by Isabell Koske, Deputy Director, Country Studies Branch, Economics Department.

All Economics Department Working Papers are available at www.oecd.org/eco/workingpapers

JT03456120 
OECD Working Papers should not be reported as representing the official views of the OECD or of its member countries. The opinions expressed and arguments employed are those of the author(s).

Working Papers describe preliminary results or research in progress by the author(s) and are published to stimulate discussion on a broad range of issues on which the OECD works.

Comments on Working Papers are welcomed, and may be sent to the Economics Department, OECD, 2 rue André-Pascal, 75775 Paris Cedex 16, France, or by e-mail to eco.contact@oecd.org.

$\begin{array}{llllll}\text { All Economics Department } & \text { Working Papers are available at } \\ \text { www.oecd.org/eco/workingpapers. } & & & & \end{array}$

You can copy, download or print OECD content for your own use, and you can include excerpts from OECD publications, databases and multimedia products in your own documents, presentations, blogs, websites and teaching materials, provided that suitable acknowledgment of OECD as source and copyright owner is given. All requests for commercial use and translation rights should be submitted to rights@,oecd.org 


\section{ABSTRACT/RESUMÉ}

\section{What drives the performance of Swedish lower secondary schools?}

This paper presents the econometric analysis of lower secondary school performance carried out for the chapter on education of the 2019 OECD Economic Survey of Sweden. The dataset covers most Swedish schools providing education for 9th graders. Student socio-economic background has a considerable impact on academic results. Policy inputs are also correlated with results, notably in schools with pupils from weaker socio-economic backgrounds, but teacher qualifications and spending per student are endogenous. For-profit private schools underperform compared to non-profit and public schools, albeit with strong heterogeneity between schools. The introduction of an indicator of competition, based on the density of schools, suggests that intensified school competition lowers results in schools with a high share of pupils from weaker socio-economic backgrounds. Schools, and especially those achieving weaker results, have scope to raise their performance by improving their adaptation to student needs.

This Working Paper relates to the 2019 OECD Economic Survey of Sweden http://www.oecd.org/economy/sweden-economic-snapshot/

JEL classification codes: C23, H75, I21, I28.

Keywords: Sweden, education, efficiency, competition, stochastic frontier analysis.

$* * * * * * * * * * * * *$

\section{Quels sont les déterminants des performances des écoles suédoises du premier cycle de l'enseignement secondaire?}

Ce document présente l'analyse économétrique des performances des écoles du premier cycle de l'enseignement secondaire réalisée pour le chapitre sur l'éducation de l'Étude économique de l'OCDE de la Suède 2019. Les données utilisées couvrent la plupart des écoles suédoises dispensant un enseignement aux élèves de 9ème année. L'origine socio-économiques des élèves a un impact considérable sur les résultats scolaires. Les facteurs de politique sont également corrélés avec les résultats, notamment pour les écoles dont les élèves sont issus des milieux socio-économiques les plus modestes, mais les qualifications des enseignants et les dépenses par élève sont endogènes. Les établissements privés à but lucratif ont des performances en moyenne inférieures à celles des établissements publics ou à but non lucratif, avec toutefois une forte hétérogénéité entre les établissements. L'introduction d'un indicateur de compétition entre écoles, basé sur la densité d'établissements, suggère que la compétition affecte négativement les résultats des écoles dans lesquelles la proportion d'élèves issus des milieux socio-économiques les plus modestes est forte. Les écoles, et en particulier celles qui obtiennent les résultats les plus faibles, ont la possibilité d'augmenter leurs performances en améliorant leur adaptation aux besoins des élèves.

Ce Document de travail se rapporte à l'Étude économique de l'OCDE de la Suède 2019

http://www.oecd.org/fr/economie/suede-en-un-coup-d-oeil/

Codes de classification JEL : C23, H75, I21, I28

Mots-clés : Suède, éducation, efficience, compétition, analyse de frontière stochastique. 


\section{Table of contents}

What drives the performance of Swedish lower secondary schools?................................................... 5

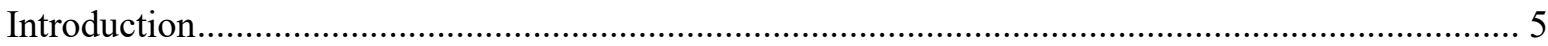

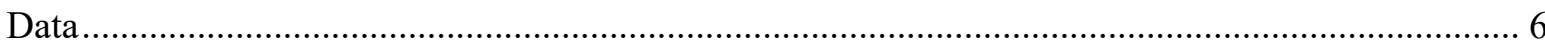

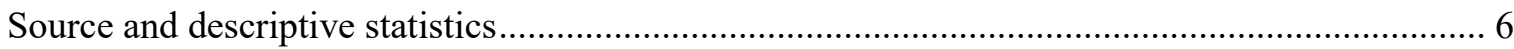

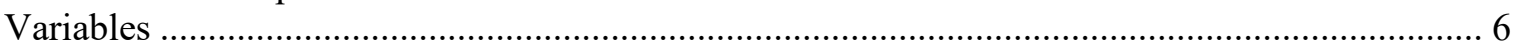

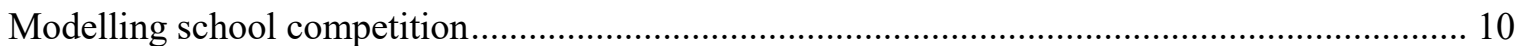

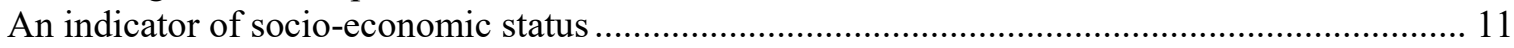

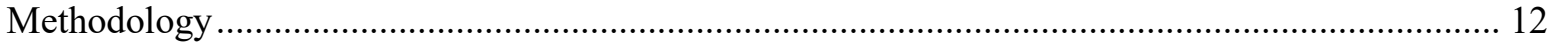

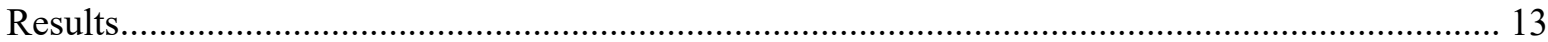

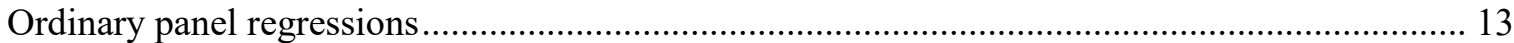

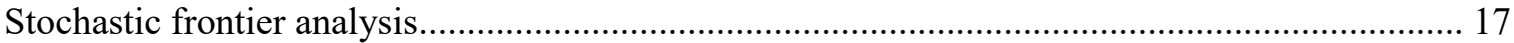

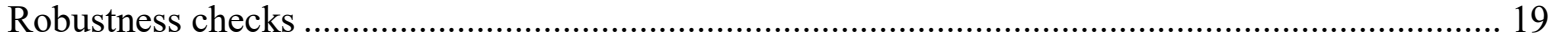

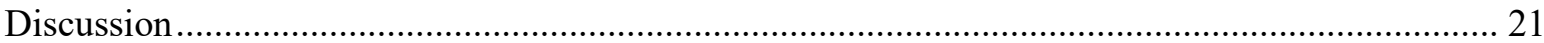

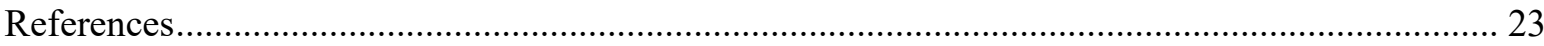

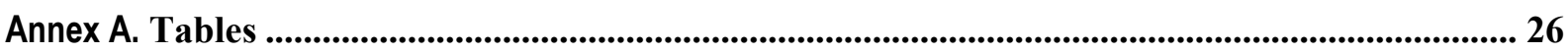

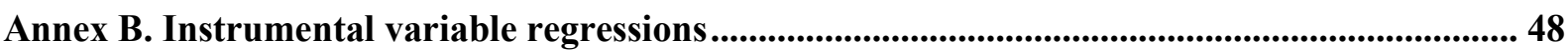

\section{Tables}

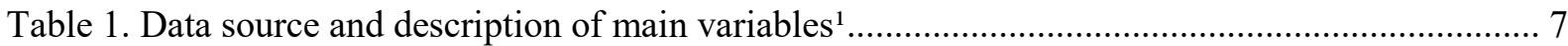

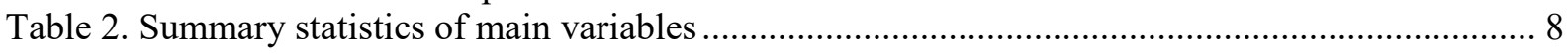

Table 3. Averages by type of schools and tests for differences ........................................................ 9

Table 4. Main results from regressions on mathematics test scores..................................................... 14

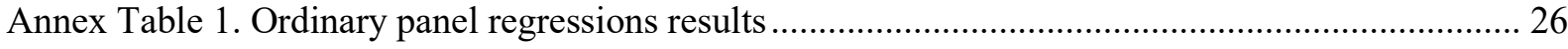

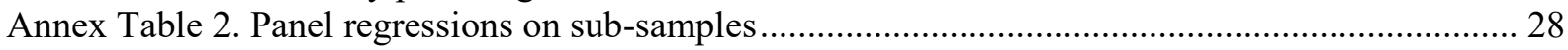

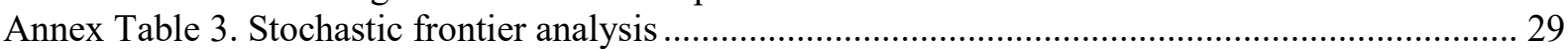

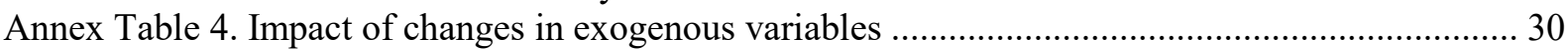

Annex Table 5. Model with one policy variable at a time (fixed effects) …....................................... 32

Annex Table 6. Model with one policy variable at a time (random effects) ...................................... 33

Annex Table 7. Ordinary panel regressions with alternative survey measures ..................................... 34

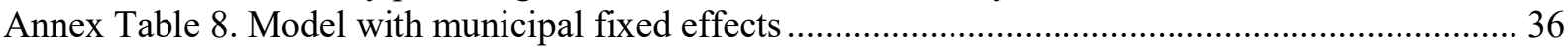

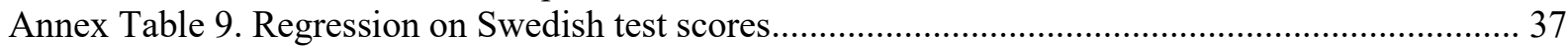

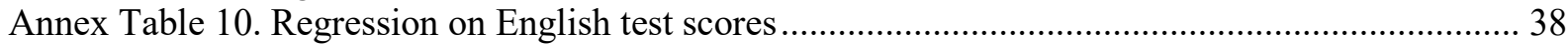

Annex Table 11. Robustness check for the competition indicator - share of pupils in private schools 39

Annex Table 12. Robustness check for the competition indicator - share of pupils in private schools 40

Annex Table 13. Robustness check for the competition indicator - share of pupils in private schools 41

Annex Table 14. Robustness check for the competition indicator - distance between schools ............ 43

Annex Table 15. Robustness check for the competition indicator - distance between schools ............ 44

Annex Table 16. Robustness check for the competition indicator - distance between schools ............ 45

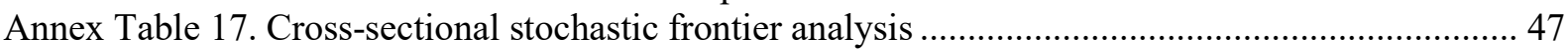

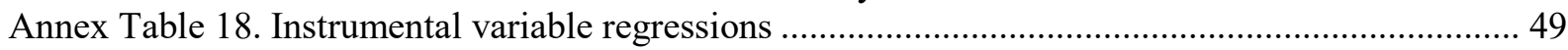

Figures

Figure 1. Distribution of inefficiency scores . 


\title{
What drives the performance of Swedish lower secondary schools?
}

\author{
By Christophe André, Jon Pareliussen and Hyunjeong Hwang ${ }^{1}$
}

\section{Introduction}

Sweden has a strong knowledge-based economy, which relies heavily on a highly skilled workforce. However, over recent years results from the Programme for International Student Assessment (PISA) for 15-year olds have been disappointing. Even though the 2015 rankings improved over those from 2012, they are only on par with the OECD average. Furthermore inequality in educational achievement is rising. Strong immigration in 2015-16 has put additional pressure on municipalities and schools, and a projected increase of 300000 in the population aged below 20 by 2025 poses a further challenge. Against this background, the 2019 OECD Economic Survey of Sweden complements previous analyses of the Swedish education system (OECD, 2015 $5_{[1]}$; OECD, 2015 $5_{[2]}$ ) with a more specific analysis of the performance of lower secondary schools.

This paper presents an econometric analysis of a panel of Swedish lower secondary schools to identify the main drivers of school performance, measured by average scores in national mathematics tests. Conventional panel regressions are performed, along with stochastic frontier analysis, which sheds light on the level and distribution of school inefficiencies. Related policy issues are discussed in more detail in a companion paper (Pareliussen, André and Hwang, 2019[3]).

The main findings are as follows:

- Four policy variables are related to schools' average mathematics test scores. A survey indicator of adaptation of education to student needs has the strongest impact. The number of pupils per teacher has a negative but statistically insignificant effect. Spending per pupil and the share of certified teachers are positively associated with test scores, but are endogenous and when this is taken into account, they become statistically insignificant.

- The relation between inputs and test scores varies between schools with weak and strong socio-economic mixes of students. In particular, the positive association between test scores and both spending per pupil and the share of certified teachers is stronger in weaker schools.

- The between- and within-school effects of each policy and socio-economic variables are somewhat different, pointing to school heterogeneity with respect to responses to differences in inputs and environment.

- Non-profit private school results are on par with those of public schools, but forprofit schools show somewhat lower results on average, controlling for other drivers of performance. However, this effect masks large heterogeneity across schools. The under-performance of for-profit schools is more pronounced in

\footnotetext{
${ }^{1}$ The authors would like to thank Vincent Koen, Zuzana Smidova (OECD Economics Department), Jeffrey Mo (OECD Education Directorate), Henrik Jordahl, Gabriel Heller Sahlgren, Jonas Vlachos, Swedish government officials and participants in an OECD Economics Department internal seminar for useful comments and suggestions on earlier versions of this paper, and Sisse Nielsen for excellent editorial assistance.
} 
schools with a weaker socio-economic mix of students, while non-profit private schools over-perform in that category of schools.

- An indicator of competition, based on the density of schools in the vicinity of each school, has a negative effect on test scores, albeit only in schools with a weak socioeconomic mix of students. This result is confirmed using the share of pupils in private schools by municipality as a competition indicator.

- Stockholm, Gothenburg and Malmö outperform the rest of the country, thanks to the high performance of the schools in the top of the socio-economic distribution.

- Stochastic frontier analysis points to an average level of inefficiency of about $10 \%$ and a relatively narrow distribution of inefficiency.

Data

\section{Source and descriptive statistics}

The empirical analysis is based on an unbalanced panel data set containing school-level and municipal-level data, covering 1346 schools and 286 municipalities from 2013 to 2017. ${ }^{2}$ Data sources are shown in Table 1. The primary data source is the Swedish Agency for Education's (Skolverket) online information system, SIRIS/SALSA (Swedish Agency for Education, 2018 $8_{[4]}$ ). It provides school-level datasets on school performance, as well as teacher and student characteristics. Municipal-level data on demographics are collected from Statistics Sweden (SCB) $\left(2018_{[5]}\right)$. Finally, results from a school-level survey of student satisfaction (Skolenkäten) are gathered from the School inspectorate (2018[6]). The data is merged by unique school and municipality identifiers.

After removing a few outliers, the whole sample includes 4878 observations, of which 3735 come from public schools (77\%), 973 from for-profit schools (20\%) and 170 from nonprofit private schools $(3 \%)$. The coverage varies slightly between years. On average over the five years, the sample covers two-thirds of the total number of schools in Sweden, with a minimum of $58 \%$ in 2013 and a maximum of $72 \%$ in 2016.

\section{Variables $^{3}$}

Summary statistics for the main variables are shown in Table 2. The dependent variable is a simple school-level average mathematics score from the national test in the ninth grade. Vlachos $\left(2018_{[7]}\right)$ finds evidence of systematic differences in grading standards between Swedish schools, and argues that the national test score in mathematics is more reliable than other subject scores, as grading is less subjective. ${ }^{4}$ The Swedish School Inspectorate $\left(2013_{[8]}\right)$ found that mathematics has the smallest discrepancy between external and internal assessments among the core subjects in national tests, which also include Swedish and English. As a robustness check, regressions are also run with Swedish reading test scores

\footnotetext{
2 The dataset expands in time and scope the dataset used in Vlachos $\left(2018_{[7]}\right)$.

${ }^{3}$ This section describes the variables used in the main regressions. Additional variables used in instrumental variable regressions are described in Annex B.

${ }^{4}$ National tests are graded locally by the subject teacher. Swedish and English tests include writing and speaking performance, and the English test also includes listening. Room for subjective interpretation of vague assessment directives is higher than in mathematics.
} 
and English reading and listening test scores, results considered the most objective following mathematics.

Table 1. Data source and description of main variables ${ }^{1}$

\begin{tabular}{|c|c|c|c|}
\hline Category & Level & Time variance & Source \\
\hline \multicolumn{4}{|l|}{ Dependent } \\
\hline Mathematics test score & school-level & yes & Skolverket \\
\hline \multicolumn{4}{|l|}{ Policy variables } \\
\hline Spending per pupil & municipal-level & yes & Skolverket \\
\hline Pupils per teacher & school-level & yes & Skolverket \\
\hline Share of certified teachers ${ }^{2}$ & school-level & yes & Skolverket \\
\hline Adaptation to student needs & school-level & no & Skolinspektionen \\
\hline \multicolumn{4}{|l|}{ Socio-economic variables } \\
\hline Share of new immigrants & school-level & yes & Skolverket \\
\hline Parent education level (index) ${ }^{3}$ & school-level & yes & Skolverket \\
\hline Share of boys & school-level & yes & Skolverket \\
\hline \multicolumn{4}{|l|}{ School type dummies ${ }^{4}$} \\
\hline For-profit & school-level & no & Skolverket \\
\hline Non-profit & school-level & no & Skolverket \\
\hline \multicolumn{4}{|l|}{ Functional labour market dummies } \\
\hline Greater Stockholm & municipal-level & no & Statistics Sweden \\
\hline Greater Göteborg & municipal-level & no & Statistics Sweden \\
\hline Greater Malmö & municipal-level & no & Statistics Sweden \\
\hline \multicolumn{4}{|l|}{ Competition } \\
\hline Density & school-level & no & OECD calculations \& HERE API \\
\hline \multicolumn{4}{|l|}{ Instrument variables } \\
\hline Share of female teachers & school-level & yes & Skolverket \\
\hline Young-age dependency ratio & municipal-level & yes & Statistics Sweden \\
\hline \multicolumn{4}{|l|}{ Other variables for robustness } \\
\hline English score / Swedish score & school-level & yes & Skolverket \\
\hline Share of pupils in private schools & municipal-level & yes & OECD calculations \& Skolverket \\
\hline Distance between schools & school-level & yes & OECD calculations \& HERE API \\
\hline
\end{tabular}

1. Absolute values (i.e., mathematics test score and spending per pupil) are converted to natural logarithms. Academic years are referred to by their ending year (e.g., year 2014 refers to the academic year 2013/2014).

2. When data on teacher certification is missing, values are imputed using the procedure from Vlachos (2018). Specifically, the school-level mean value of teacher certification for non-missing years within each subject is used. When this is not possible, the mean school share of certified teachers for other subjects within the following subject groups is used: Swedish, English, science, social science, and aesthetic/practical subjects.

3. Education level is based on both parents' highest educational attainment and ranges from 1 to 3 .

4. For-profit schools include schools owned by limited companies except banking and insurance companies, economic associations other than tenant-owner associations, trading company, and limited company. Nonprofit schools include schools owned by registered religious communities, non-profit organisations, other foundations and funds including pension foundations and staff foundations.

The main analysis includes four policy variables: spending per pupil, pupils per teacher, share of certified teachers, and adaptation to student needs. These variables reflect policy choices that can affect school performance:

- Spending per pupil refers to total expenditure on compulsory schools divided by the total number of pupils at the municipal level. According to the definition 
provided by Skolverket, the cost includes staff, teaching tools, school libraries, school management, administration, and professional development of teachers and staff. The variable may suffer from endogeneity, as poorly-performing schools may receive more funding. ${ }^{5}$

- The school-level share of certified teachers qualified to teach in their subject (here mathematics) is a commonly used predictor of student achievement. It is often considered the most reliable among various measures of teacher quality (DarlingHammond 2000), but may suffer from endogeneity, as qualified teachers generally prefer working in high-performing schools (Andersson and Waldenström, 2007[9]).

- The pupil-to-teacher ratio is the number of pupils divided by the number of fulltime equivalent teachers at the school.

- Adaptation to student needs is based on the School Inspectorate's Student Satisfaction Survey (Skolenkäten). The questionnaire contains a total of 14 items on the school climate such as conditions for learning, physical safety and emotional support. Each survey question is given as a statement, and pupils are asked to assess whether this statement corresponds to their own experience on a four-point scale ranging from "corresponds completely" to "does not correspond at all". "I do not know" is included as a fifth option. These answers are translated into numerical scores of 10, 6.67, 3.33 and 0 , respectively, and answers of "I do not know" are excluded. The variable used in our main analysis is the school-level score under item four, "Adaptation to the pupil's needs", which is the average of responses to three questions/statements ("I can get extra tutoring if I should need it", "My teachers help me with my school work when I need it" and "School work is difficult for me"). Consistency checks are carried out with the 13 other survey items. As the survey items are positively correlated at the $1 \%$ significance level, only one at a time is included in the regressions to avoid multicollinearity.

Table 2. Summary statistics of main variables

\begin{tabular}{|c|c|c|c|c|c|}
\hline & Mean & Standard deviation & Min & Max & Observations \\
\hline \multicolumn{6}{|l|}{ Whole sample } \\
\hline Mathematics test score & 11.5 & 2.1 & 2.9 & 18.9 & 4878 \\
\hline \multicolumn{6}{|l|}{ Policy variables } \\
\hline Spending per pupil (SEK) & 96555 & 10220 & 72800 & 137800 & 4878 \\
\hline Pupils per teacher & 12.6 & 2.4 & 1.6 & 42.1 & 4878 \\
\hline Share of certified teachers $(\%)$ & 72.1 & 20.5 & 0.0 & 100.0 & 4878 \\
\hline Adaptation to student needs & 6.9 & 0.6 & 4.5 & 8.8 & 4878 \\
\hline \multicolumn{6}{|l|}{ Socio-economic variables } \\
\hline Share of new immigrants ( $\%)$ & 4.4 & 6.4 & 0.0 & 51.0 & 4878 \\
\hline Share of boys (\%) & 51.8 & 9.0 & 0.0 & 100.0 & 4878 \\
\hline Parent education level (index) ${ }^{1}$ & 2.3 & 0.2 & 1.3 & 3.0 & 4878 \\
\hline \multicolumn{6}{|l|}{ Competition } \\
\hline Density & 0.8 & 1.0 & 0.0 & 5.6 & 4878 \\
\hline
\end{tabular}

1. Education level is based on the highest level of education attained by each parent and runs from 1 to 3 .

\footnotetext{
${ }^{5}$ This is an empirical question, as school funding is set at the discretion of each municipality, with the exception of some targeted state grants. Spending per pupil and average mathematics test scores exhibit a slightly negative correlation.
} 
Differences in the socio-economic background of students are controlled for by the share of newly arrived migrants and the parental education level. The share of boys is also included to account for systematic differences in results between genders. The share of new immigrants is defined as the share of students who immigrated less than four years before completing compulsory education. The parental education level is measured with an index where each parent is assigned a score of one if their highest-achieved level of education is at the lower secondary level or below, two if it is upper secondary education, and three if it is tertiary education. The index value is the parents' average education level, ranging from one to three. Controls are included for the school owner (municipal, private for-profit and private non-profit). Finally, dummies for the functional labour market regions (LAregions) centred around the three main agglomerations of Stockholm, Gothenburg and Malmö are added. Functional labour market regions are based on commuting patterns in the LA15 update from Statistics Sweden (2018[10]).

The average policy settings and student characteristics vary across types of schools (Table 3). The average mathematics test score is highest in non-profit private schools, followed by for-profit schools. Spending per pupil is also somewhat higher in private than in public schools, reflecting differences in location, as municipalities are obliged to fund private and public schools equivalently. For-profit schools have a markedly lower share of certified teachers than other schools. Private schools are perceived to adapt education better to student needs, and non-profit schools even more so than for-profit schools. Private school students have on average more favourable socio-economic characteristics, with far fewer new immigrants, a lower share of boys and parents with higher average education attainment. They are also more subject to competition as they are on average located in areas with a higher density of schools.

Table 3. Averages by type of schools and tests for differences

\begin{tabular}{|c|c|c|c|c|c|}
\hline \multirow{2}{*}{ Dependent variable } & \multicolumn{5}{|c|}{ Averages by group } \\
\hline & Public & \multicolumn{2}{|c|}{ For-profit ${ }^{1}$} & \multicolumn{2}{|c|}{ Non-profit ${ }^{2}$} \\
\hline Mathematics test score & 11.3 & 12.2 & $* * *$ & 13.6 & 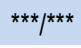 \\
\hline \multicolumn{6}{|l|}{ Policy variables } \\
\hline Spending per pupil (SEK) & 96143 & 97579 & ** & 99710 & $* * * / * \star *$ \\
\hline Pupils per teacher & 12.3 & 14 & $* * *$ & 12.3 & $\mu^{* * *}$ \\
\hline Share of certified teachers (\%) & 73.6 & 66.2 & $* * *$ & 72.3 & $* * * / * *$ \\
\hline Adaptation to student needs & 6.9 & 7.1 & $* * *$ & 7.4 & $* * * / * *$ \\
\hline \multicolumn{6}{|l|}{ Socio-economic variables } \\
\hline Share of new immigrants (\%) & 5.4 & 0.9 & $* * *$ & 1.3 & $* * *$ \\
\hline Share of boys (\%) & 52.6 & 50 & $* * *$ & 46.3 & $* * \star / * \star *$ \\
\hline Parents' education (index) & 2.2 & 2.4 & $* * *$ & 2.5 & $* * \star / * \star *$ \\
\hline \multicolumn{6}{|l|}{ Competition } \\
\hline Density & 0.7 & 1.0 & $* * *$ & 1.5 & $* * * / * * *$ \\
\hline
\end{tabular}

$* * *, * *$ and $*$ indicate significant differences between the means of two groups at the $1 \%, 5 \%$ and $10 \%$ level, respectively.

1. The significance tests are conducted for the comparison with public schools.

2. The significance test results are reported for comparisons with public schools (left) and for-profit schools (right). 


\section{Modelling school competition}

Earlier studies found a positive relationship between school competition and results. Böhlmark and Lindahl $\left(2015_{[11]}\right)$ found positive effects from the share of students attending private schools on average grades within a municipality with a dataset covering the period 1988-2009. Wondratschek et al. (2013 [12] $)$ used a measure based on the number of schools in the vicinity of pupils' homes covering the period 1987-2006, and found a significant but very small positive effect from having more choices available. The competition indicator constructed to test the relationship between school competition and results in this paper follows a similar logic to Wondratscheck et al. $\left(2013_{[12]}\right)$ and Misra, Grimes and Rogers $\left(2012_{[13]}\right)$, but with some differences, as outlined below.

Parents in Sweden are allowed to freely choose the school where they place their children. Among public schools, the choice is limited to schools within the municipality of residence, while attendance at private schools is not limited by municipal borders. The indicator is therefore constructed such that competition for private schools comes not only from the same municipality but also from neighbouring municipalities in border areas (Misra, Grimes and Rogers, 2012[13]). Therefore, for private schools, competing schools can be any type of school (i.e. private or public) within a specified travel time. For public schools, competition comes from public schools in the same municipality and private schools within the specified travel time. Travel times between any pair of schools within our dataset are retrieved using the STATA user-written syntax ' georoute' ${ }^{6}{ }^{6}$ Travel time refers to the time to drive the distance under normal traffic conditions.

The main indicator, the "density" indicator of competition, is constructed by simply counting the number of competing schools within a 15-minute radius.

An alternative indicator, the "distance" competition indicator, was calculated in a gravityinspired framework. Contrary to Misra, Grimes and Rogers $\left(2012_{[13]}\right)$, the size of schools is not taken into account, as there is no clear rationale for assuming that larger schools are more attractive than smaller ones in general. Competition between any two schools is defined by the inverse of the square of the travel time between them. The competition indicator for any school takes the value of the sum of competition from all other schools within the time limit. The maximum travel time between schools is limited to 15 minutes so that competition from schools outside this radius is assumed to be zero. Both competition indicators have been standardised to a unit standard deviation to facilitate the presentation of the results.

The density competition indicator can be expressed as follows.

For a private school:

$$
A_{i}=\sum_{j \neq i}^{n} K_{j}
$$

where

$K_{j}=1$ if $d_{i j}<15$, and $K_{j}=0$ otherwise.

\footnotetext{
${ }^{6}$ For more detail, see Weber et al. $\left(2016_{[29]}\right)$.
} 
$d_{i j}$ is the travel time in minutes between school $i$ and $j$.

For a public school:

$$
B_{i}=\sum_{\ell \neq i}^{p} K_{\ell}+\sum_{t \neq i}^{m} K_{t}
$$

where

$K_{\ell}=1$ if $\ell=$ private school and $d_{i \ell}<15 . K_{\ell}=0$ otherwise.

$K_{t}=1$ if $t=$ public school in the same municipality and $d_{i t}<15 . K_{t}=0$ if not.

$d_{i \ell}\left(d_{i t}\right)$ is the travel time in minutes between school $i$ and $\ell(t)$.

Similarly, the distance competition indicator can be expressed as below.

For a private school:

$$
A_{i}=\frac{1}{\mathrm{n}} \sum_{j \neq i}^{n}\left(d_{i j}^{-2}\right)
$$

where

$d_{i j}$ is the travel time in minutes between school $i$ and $j$, defined for $d_{i j}<15$.

For a public school:

$$
B_{i}=\frac{1}{\mathrm{p}} \sum_{\ell \neq i}^{p}\left(d_{i \ell}^{-2}\right)+\frac{1}{m} \sum_{t \neq i}^{m}\left(d_{i t}^{-2}\right)
$$

where

$\ell=$ private school.

$t=$ public school in the same municipality as school $i$.

$d_{i \ell}$ is the travel time in minutes between school $i$ and $\ell(t)$, defined for $d_{i \ell}<15$.

$d_{i t}$ is the travel time in minutes between school $i$ and $\ell(t)$, defined for $d_{i t}<15$

1. As a consistency check, the share of students attending private schools within a municipality is included as an alternative competition measure, following Böhlmark and Lindahl $\left(2015_{[11]}\right)$.

\section{An indicator of socio-economic status}

An indicator of socio-economic status is constructed for the purpose of sorting the data to analyse different sub-samples. The indicator is constructed by predicting counter-factual national mathematics test scores with the regression coefficients of the socio-economic variables from the main specification. All other covariates are assumed to take a constant value, equal for all schools. The schools are thus ranked by the predicted test scores assuming the only difference between them is the share of newly arrived migrants, the share of boys and the parental education level. 


\section{Methodology}

The model estimates a production function of educational outcomes, using various panel regression models, with fixed or random effects, as well as panel stochastic frontier analysis. The basic model can be written as follows:

$$
\mathrm{y}_{\mathrm{it}}=\alpha+\mu_{\mathrm{i}}+\gamma_{\mathrm{t}}+\beta \mathrm{x}_{\mathrm{it}}+\delta \mathrm{w}_{\mathrm{i}}+\varepsilon_{\mathrm{it}}
$$

where $\mathrm{y}_{\text {it }}$ is the natural logarithm of the average mathematics test result of school $i$ in year $t, \alpha$ is a constant, $\mu_{\mathrm{i}}$ are school effects, $\gamma_{\mathrm{t}}$ are year fixed effects accounting for the variation in average test scores over time, $\mathrm{x}_{\mathrm{it}}$ is a matrix of time-varying variables, $\mathrm{w}_{\mathrm{i}}$ is a matrix of time-invariant variables and $\varepsilon_{\mathrm{it}}$ are random errors.

The full model in equation (1) can only be estimated using random school effects, as it includes time-invariant variables. However, the random effect (RE) model assumes the absence of correlation between the school effects and the regressors, an assumption which may not hold, in which case the RE coefficients would be biased and inconsistent. In that case, the fixed effects (FE) model would yield unbiased estimators, but it also has significant drawbacks. First, it does not allow the inclusion of time-invariant regressors. Second, the FE model simply ignores cross-sectional information. In a sample where the number of schools is far larger than the number of years, this is likely to result in a huge loss of information. Finally, while the FE model yields unbiased and consistent estimates of the slope coefficients, it does not yield consistent estimates of the fixed effects because of the incidental parameters problem (i.e. the number of parameters increases with the number of cross-sections). While this is a minor issue in traditional panel regressions, where the value of the fixed effect may be of limited interest, it has serious implications for stochastic frontier analysis, as it is bound to affect the efficiency estimates (Belotti et al., $\left.2013_{[14]}\right)$.

An alternative to the traditional $\mathrm{FE}$ and RE models is the random effects within-between (REWB) model (Bell and Jones, 2015 $5_{[15]}$ ), which can be written as:

$\mathrm{y}_{\mathrm{it}}=\alpha+\mu_{\mathrm{i}}+\gamma_{\mathrm{t}}+\beta^{\mathrm{W}}\left(\mathrm{x}_{\mathrm{it}}-\overline{\mathrm{x}}_{\mathrm{i}}\right)+\beta^{\mathrm{B}} \overline{\mathrm{x}}_{\mathrm{i} .}+\delta \mathrm{w}_{\mathrm{i}}+\varepsilon_{\mathrm{it}}$

where $\bar{x}_{i}$ is the average over time of time-varying variables for each school.

The REWB model distinguishes the impacts of exogenous variables within schools $\left(\beta^{\mathrm{W}}\right)$ and between schools $\left(\beta^{\mathrm{B}}\right)$. In this model, variations in inputs across time and within crosssections are allowed to have different effects, which is a plausible assumption as schools are heterogeneous and may need time to adapt to variations in their inputs. The REWB model removes the potential heterogeneity bias resulting from unduly imposing equality between the within and between effects in the traditional RE model and shows better statistical properties than the RE and the FE model in the presence of heterogeneity across units (Bell and Jones, 2015 $[15]$ ).

In this paper, the focus is on the RE model, which has the decisive advantage over the FE model of allowing the inclusion of time-invariant variables and taking into account crosssectional information. It makes the presentation of results more straightforward than the REWB model, as it provides a unique coefficient for each variable. However, one needs to bear in mind that this simplicity comes at the price of weaker statistical properties and a somewhat ambiguous interpretation of the coefficients, which are averages of effects over time and across schools that differ in magnitude. Therefore, the FE and REWB models are used as complements and consistency checks. 
A limitation of ordinary panel regressions is that they assume that errors are distributed symmetrically. As the relation estimated in this paper is a production function, this will not be the case, unless schools are all fully efficient. Otherwise, inefficiency, measured as a distance to the production frontier, will be incorporated in the error term. As schools can only be located below the frontier, the error term will be skewed. This issue can be addressed using panel stochastic frontier analysis (SFA), which decomposes the error-term into a symmetric term, accounting for measurement and specification errors, and an asymmetric term, measuring inefficiency.

Equation (1) can be modified as follows:

$\mathrm{y}_{\mathrm{it}}=\alpha+\mu_{\mathrm{i}}+\gamma_{\mathrm{t}}+\beta \mathrm{x}_{\mathrm{it}}+\delta \mathrm{w}_{\mathrm{i}}+\mathrm{v}_{\mathrm{it}}-\mathrm{u}_{\mathrm{it}}$

where $v_{i t}$ is a normally distributed random error and $u_{i t}$ is a positive or nil inefficiency term. In most regressions in this paper, $\mathrm{u}_{\mathrm{it}}$ is assumed to follow an exponential distribution, but robustness checks are carried out assuming a half-normal distribution.

The REWB model in equation (2) can be transformed into an SFA model in a similar way.

Several variants of the SFA model described in equation (3) have been proposed in the literature (Pitt and Lee, 1981 [16]; Battese and Coelli, 1988 ${ }_{[17]}$; Schmidt and Sickles, $1984_{[18]}$; Battese and Coelli, 1995 $[19])$. In this paper, the "true" random effects variant (Greene, $2005_{[20]}$ ) is used. Its main advantages are to allow time variation in inefficiency, without imposing a deterministic structure on its time path, and a better separation of inefficiency from time-invariant heterogeneity than in earlier models.

A final econometric issue is the potential endogeneity of some regressors, notably the share of certified teachers and spending per pupil. This issue is addressed using instrumental variables.

\section{Results}

\section{Ordinary panel regressions}

A range of models have been estimated, starting with ordinary panel regressions including only time-varying policy variables. Controls and variables displaying no time variation are subsequently added. Regressions on subsets of the sample are run to assess potential differences in the impact of exogenous variables across schools with different student socio-economic backgrounds and average test scores. Finally, stochastic frontier analysis yields estimates of school inefficiency. The main results are shown in Table 4, and detailed results tables are included in Annex A.

The fixed and random effect models including only time-varying policy variables show diverging results (columns 1 and 2 in Annex Table 1). Only the share of certified teachers is statistically significant in the FE model, while all three policy variables are significant in the RE model. However, in the latter the number of pupils per teacher is positively correlated with the test scores, which is contrary to expectations. The Hausman test confirms that coefficients from the fixed and random effects models differ $\left(\chi^{2}=104.1\right.$, $\mathrm{p}=0.00$ ). Next, controls for environmental factors influencing school results, namely the shares of new immigrants, boys and the parental education level, are introduced. These variables are statistically significant and the results from the FE and RE models become closer (columns 3 and 4 in Annex Table 1). Nevertheless, the Hausman test still rejects the hypothesis of equality of the FE and RE coefficients $\left(\chi^{2}=28.1, p=0.00\right)$. 
Table 4. Main results from regressions on mathematics test scores

\begin{tabular}{|c|c|c|c|c|c|c|c|c|c|c|}
\hline \multirow{3}{*}{ Model type } & \multicolumn{4}{|c|}{ ORDINARY PANEL REGRESSION RESULTS } & \multicolumn{2}{|c|}{ SUB-SAMPLE } & \multirow{2}{*}{$\begin{array}{c}\text { SFA } \\
\text { SFA[7] }\end{array}$} & \multicolumn{3}{|c|}{ STANDARD DEVIATION IMPACT } \\
\hline & $\mathrm{RE}[1]$ & REWB[2] & $\mathrm{RE}[3]$ & $\mathrm{RE}[4]$ & $\mathrm{RE}[5]$ & $\mathrm{RE}[6]$ & & Impact[8] & Impact[9] & Impact[10] \\
\hline & & & $\begin{array}{c}\text { Endogenous } \\
\text { teachers }\end{array}$ & $\begin{array}{c}\text { Endogenous } \\
\text { spending }\end{array}$ & $\begin{array}{l}\text { Bottom } \\
\text { quartile }\end{array}$ & $\begin{array}{c}\text { Top } \\
\text { quartile }\end{array}$ & Exponential & $\mathrm{RE}[1]$ & $\mathrm{RE}[5]$ & $\mathrm{RE}[6]$ \\
\hline \multicolumn{11}{|l|}{ Policy variables } \\
\hline Spending per pupil & $0.091^{* * *}$ & $0.090^{* *} / 0.100^{\star *}$ & $0.101^{* \star *}$ & 0.006 & $0.180^{* *}$ & 0.0468 & $0.063^{* \star *}$ & 0.053 & 0.102 & 0.027 \\
\hline Pupils per teacher & 0.000 & $-0.001 /-0.001$ & -0.000 & -0.001 & -0.000 & 0.002 & -0.001 & -0.002 & -0.001 & 0.029 \\
\hline Share of certified teachers & $0.080^{\star \star \star}$ & $0.100^{* * *} / 0.039^{* *}$ & -0.131 & $0.064^{\star \star *}$ & $0.112^{* \star *}$ & 0.022 & $0.046^{* \star *}$ & 0.089 & 0.125 & 0.025 \\
\hline Adaptation to student needs & $0.050^{* * *}$ & $0.046^{* * *}$ & $0.055^{* \star *}$ & $0.048^{\star \star *}$ & $0.056^{* * *}$ & $0.035^{* * *}$ & $0.040^{* \star *}$ & 0.151 & 0.170 & 0.106 \\
\hline \multicolumn{11}{|l|}{ School type } \\
\hline For-profit & $-0.028^{\star * *}$ & $-0.039^{\star * *}$ & $-0.050^{\star * *}$ & $-0.029^{\star * *}$ & $-0.049^{*}$ & -0.012 & -0.000 & -0.060 & -0.108 & -0.026 \\
\hline Non-profit & 0.006 & -0.012 & -0.010 & 0.002 & $0.191^{* *}$ & 0.006 & 0.024 & 0.006 & 0.192 & 0.006 \\
\hline \multicolumn{11}{|l|}{ Socio-economic variables } \\
\hline Share of new immigrants & $-0.308^{* * *}$ & $-0.269^{\star \star *} /-0.308^{\star \star *}$ & $-0.338^{* * *}$ & $-0.309^{* * *}$ & $-0.407^{* * *}$ & $-0.263^{* \star}$ & $-0.247^{* * *}$ & -0.108 & -0.143 & -0.092 \\
\hline Share of boys & $-0.060^{\star *}$ & $-0.056^{\star \star} /-0.082$ & $-0.051^{* *}$ & $-0.061^{* *}$ & $-0.146^{\star *}$ & $-0.048^{*}$ & $-0.049^{* *}$ & -0.029 & -0.072 & -0.024 \\
\hline Parents' education & $0.442^{* * *}$ & $0.334^{\star \star \star} / 0.505^{\star \star \star}$ & $0.469^{\star \star \star}$ & $0.468^{\star \star \star}$ & $0.461^{* * *}$ & $0.391^{* * *}$ & $0.371^{* \star *}$ & 0.563 & 0.587 & 0.498 \\
\hline \multicolumn{11}{|l|}{ Municipality } \\
\hline Stockholm & $0.050^{* * *}$ & $0.046^{\star * *}$ & $0.034^{* \star *}$ & $0.051^{\star \star \star}$ & 0.008 & $0.079^{* * *}$ & $0.048^{* \star *}$ & 0.123 & 0.019 & 0.195 \\
\hline Gothenburg & $0.026^{* * *}$ & $0.022^{* *}$ & $0.022^{* *}$ & $0.024^{* * *}$ & 0.015 & $0.041^{* * *}$ & $0.027^{* \star \star}$ & 0.047 & 0.028 & 0.074 \\
\hline Malmö & $0.035^{\star * *}$ & $0.033^{* * *}$ & $0.029^{* * *}$ & $0.032^{* \star *}$ & 0.022 & $0.051^{* * *}$ & $0.039^{* * *}$ & 0.065 & 0.041 & 0.096 \\
\hline \multicolumn{11}{|l|}{ Competition } \\
\hline Density & -0.005 & -0.007 & -0.005 & -0.003 & $-0.025^{\star \star}$ & 0.002 & -0.002 & -0.029 & -0.136 & 0.013 \\
\hline Constant & 0.077 & -0.089 & 0.032 & 1.023 & -0.951 & $0.797^{*}$ & $0.737^{* \star *}$ & & & \\
\hline $\mathrm{R}^{2}$ Overall & 0.521 & 0.526 & 0.488 & 0.521 & 0.330 & 0.416 & & & & \\
\hline $\mathrm{R}^{2}$ Within & 0.287 & 0.291 & 0.254 & 0.284 & 0.316 & 0.247 & & & & \\
\hline $\mathrm{R}^{2}$ Between & 0.598 & 0.604 & 0.566 & 0.599 & 0.263 & 0.428 & & & & \\
\hline Lambda & & & & & & & $1.79^{\star * *}$ & & & \\
\hline Inefficiency (\%) & & & & & & & 9.2 & & & \\
\hline
\end{tabular}

Note: Year fixed effects are included in all regressions. The total number of observations is 4878 for the full-sample regressions, representing 1140 schools. $* * *, * *$ and * indicate significance at respectively the $1 \%, 5 \%$ and $10 \%$ level. Robust standard errors (clustered) are used. The random effects within-between model (REWB) allows between and within school coefficients to differ (Bell and Jones, 2015). The first number shows the within coefficient and the second the between coefficient. Only one coeffcient is estimated for variables without time variation. RE[3] uses the share of female teachers as an instrument for the share of certified teachers. RE[4] uses the young age dependency ratio as an instrument. RE[5] and RE[6]: quartiles are calculated after sorting schools according to the socio-economic characteristics of their students. Impact[8], Impact[9] and Impact[10] show the impact of a one standard deviation change of the exogenous variable, measured in standard deviations of the average mathematics test scores across schools. In SFA, lambda is the ratio of the variances of the asymmetric and symmetric errors. 
This would call for adopting the FE model, which yields unbiased and consistent estimators, in contrast to the RE model. However, using the FE model in this study would result in a large loss of information, as the between- $\mathrm{R}^{2}$ is much higher than the within- $\mathrm{R}^{2}$. Furthermore, variables with no time variation, such as school location and other school characteristics, cannot be added to the FE model, which results in further loss of information and potential omitted variable bias in coefficient estimates. Similarly, the variable measuring the perceived adaptation to student needs, for which only one point in time is available, would have to be ignored.

The RE model overcomes the limitations of the FE model, but at the price of potential bias and inconsistency. Nevertheless, this paper focusses on the RE model, as it is simpler than the more consistent REWB model and, as shown below, yields qualitatively similar results. Time invariant variables are introduced in the RE model. On average, schools in Stockholm, Malmö and Gothenburg show significantly better results than schools from other parts of the country (column 5 in Annex Table 1). Non-profit private school results do not differ from those of public schools, but for-profit schools have on average lower results (column 6 in Annex Table 1), a gap that becomes significant when adding the survey measure of adaptation to student needs (column 7 in Annex Table 1).

Accordingly, for an equal average level of adaptation to student needs and all other policy variables, for-profit schools underperform on average. However, for-profit schools show on average better adaptation to student needs than public schools. This variable is, at least to some extent, under the control of schools, calling for caution in the interpretation of the for-profit coefficient. Moreover, average results mask wide variation across schools. ${ }^{7}$ Adaptation to student needs is significant at the $1 \%$ level. Changes in coefficients of other variables are limited when adding adaptation to student needs, except for the for-profit school dummy. The density indicator of competition is negative but not significant when added to the equation, as shown in Table 4, column 1.

The results of the REWB model corresponding to the RE model estimated in column 1 are shown in column 2 of Table 4. The REWB model is a useful complement to the RE model, as it sheds light on school heterogeneity and the way RE model results may be interpreted. It also serves as a robustness check for the RE model, which is potentially biased. The results confirm earlier findings pointing to discrepancies between within and between effects. Although the size of coefficients varies across random, within and between effects, the results are qualitatively similar. Both within and between effects are significant at least at the $5 \%$ level for the variables that are significant in the RE model, with the exception of the between effect of the share of boys.

A potential issue with the results obtained so far is that some variables could be partly endogenous, in particular the share of certified teachers (Andersson and Waldenström, $\left.2007_{[9]}\right)$ and spending per pupil. Certified teachers are likely to select themselves into the best schools. Indeed, the proportion of certified teachers is close to $75 \%$ in the quartile of schools with the best mathematics test results over 2013-17, while it reaches only about $68 \%$ in the quartile of schools with the lowest test results. This implies that the coefficient

\footnotetext{
${ }^{7}$ When the equation in column 7 is estimated including five dummies for separate groups of private schools, independent or belonging to different companies, instead of a single dummy representing all for-profit schools, the coefficient of these dummies range from -0.035 (significant at the $5 \%$ level) to +0.115 (significant at the $1 \%$ level). This illustrates the heterogeneity among for-profit schools. The regressions are not shown to avoid providing company-specific results.
} 
measuring the impact of the share of certified teachers on average school results may be biased upwards. This assumption is tested by using as an instrument the share of female teachers, which is positively correlated with the share of certified teachers, but should be independent of school results. When endogeneity is taken into account, the hypothesis that the share of certified teachers has no impact on mathematics test results cannot be rejected (Table 4, column 3). ${ }^{8}$

Spending per pupil may also display endogeneity with respect to test scores, if more resources are allocated to schools performing poorly. This is tested using as an instrument the young age dependency ratio in the school's municipality, which is negatively correlated with spending per pupil, but should not be linked to school results, especially once socioeconomic conditions are controlled for. ${ }^{9}$ The instrument can be interpreted as reflecting a budget constraint. The results point to endogeneity and when the latter is controlled for, the impact of spending per pupil on results is no longer statistically significant (Table 4, column 4). The selection of the best students into the best schools cannot be ruled out, even though Swedish schools are not allowed to select students according to their abilities. This implies that the parents' education level may also exhibit some endogeneity. However, selfsorting of the best students into the best schools is difficult to assess using school-level data. Hence, in this paper the share of parents with upper secondary education is treated as exogenous.

The RE and REWB models are estimated without the share of certified teachers and spending per pupil, since these variables become insignificant when taking into account endogeneity (Annex Table 1, columns 12 and 13). The explanatory power of the model and the coefficients of other variables are barely affected. This supports the finding that on average, the shares of certified teachers and spending per pupil have no impact on mathematics test scores. However, these variables could have a different impact in different parts of the test score distribution. Therefore, the main regression specified in column 1 of Table 4 is run on the bottom and top quartiles of the school distribution, sorted on the socioeconomic index value (Table 4, columns 5-6). As further robustness checks, regressions are run on schools above and below the median of the same index sorted by the average school index value over the period 2013-17 to ensure that the sample of schools is similar every year (Annex Table 2), with broadly similar results. Both the share of certified teachers and spending per pupil are significantly correlated with school results in the bottom quartile, but not in the top quartile. This suggests that these inputs may matter more for schools with weak results. However, even in these sub-sample regressions, endogeneity cannot be rejected. ${ }^{10}$

Other interesting results emerge from these regressions. For-profit schools achieve lower average scores than public schools in the bottom quartile, but similar results in the top one. The negative result gap in the bottom quartile is only significant at the $10 \%$ level, likely partly due to few observations, as private schools tend to attract students of favourable socio-economic backgrounds. The results for schools below the median have stronger statistical significance, and are also negative. Non-profit private schools have higher results

\footnotetext{
${ }^{8}$ For the results of the first stage regression and validity of instrument tests, see Annex B.

${ }^{9}$ A younger population could also lower spending per pupil through economies of scale, but no relation between school size and test scores is found. Specifically, when the number of pupils is added to the equation in column 1 , its coefficient is insignificant.

${ }^{10}$ The results are not shown, but are available from the authors on request.
} 
than public schools in the lowest socio-economic quartile. The competition indicator is associated with weaker results in the bottom part of the distribution, while there is no such effect in stronger schools. The share of new immigrants has a significant negative effect both in the top and bottom quartiles, although a somewhat stronger effect in the bottom. Finally, results in Stockholm, Gothenburg and Malmö are not significantly different from the rest of the sample in the bottom quartile, but higher in the top quartile, suggesting stronger polarisation in these cities than in the overall sample (Table 4, columns 5 and 6 and Annex Table 2).

\section{Stochastic frontier analysis}

Stochastic frontier analysis (SFA) is used to account for the asymmetry in regression residuals and derive inefficiency estimates (see equation (3) above). The equation from column 1 in Table 4 is re-estimated as a "true" random effect SFA equation (Greene, $\left.2005_{[20]}\right)$. The results are qualitatively similar, despite some differences in the size of coefficients (Table 4, column 7). The main differences in coefficient significance relate to the school type. For-profit schools were found to perform below average in the ordinary panel regression, but not significantly so in the SFA model. This reflects the limited role these schools play in shaping the efficiency frontier. In SFA, their weaker performance is rather reflected in higher inefficiency scores. ${ }^{11}$

The lambda coefficient, which is the ratio of the variances of the asymmetric and symmetric errors, is significantly different from zero at the $1 \%$ confidence level, indicating that inefficiencies are present and validating the use of an SFA model. Average inefficiency is slightly below $10 \%$ and the distribution of efficiency scores is fairly narrow (Figure 1). Only about a tenth of inefficiency scores are above $20 \%$, which is a relatively moderate share in statistical terms. For comparison, the standard deviation of test scores is about $18 \%$ of the mean. Nonetheless, low efficiency can have big consequences for the pupils attending these schools, and the model suggests there is potential to improve results in these schools by moving closer to the efficiency frontier. Estimating an SFA model requires an assumption on the distribution of the inefficiency term. As a robustness check, column 2 in Annex Table 3 replicates the estimation assuming a half-normal instead of an exponential distribution. The results are very close, even though the level of inefficiency is somewhat higher using the half-normal model (approximately 12\%).

11 The average inefficiency scores are $10.7 \%$ for for-profit schools, $9.9 \%$ for public schools and $8.6 \%$ for non-profit schools. 
Figure 1. Distribution of inefficiency scores

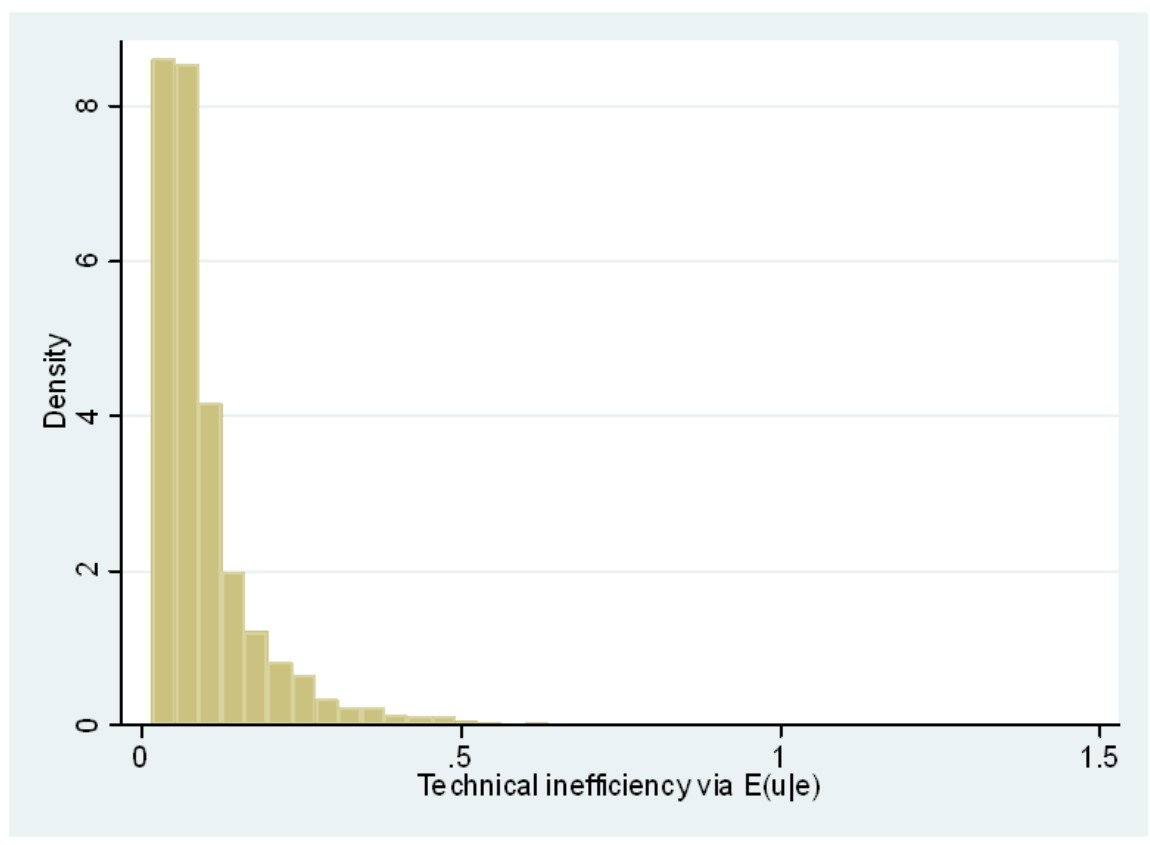

Source: Authors' calculations.

The SFA version of the REWB model yields results which are fairly similar to those of its ordinary panel regression counterpart and exhibits the same differences on for-profit schools and city dummies as the SFA RE model (Annex Table 3, column 3). Coefficients and efficiency levels remain broadly similar when endogenous variables are dropped from the RE and REWB SFA models (Annex Table 3, columns 4 and 5). Correlations and rank (Spearman) correlations between efficiency scores in the different SFA models are always above 95\%, implying that similar average efficiency estimates do not hide important variations in individual school efficiency scores and rankings.

The models estimated have identified statistically significant drivers of educational performance. To assess the magnitude of these effects, Table 4, columns 8-11 reports the impact of a change of one standard deviation in each variable. Socio-economic variables have the greatest impact on results, with a one standard deviation increase in the indicator of parent education raising mathematics test scores by more than half of a standard deviation. This result is in line with the literature ${ }^{12}$. For example, Björklund and Salvanes $\left(2011_{[21]}\right)$ argue that in every society for which data are available, education achievements are correlated with parental education level or other indicators of parents' socio-economic status, and report high correlations in education outcomes between parents and children, ranging from 0.3 to 0.5 in most countries. A 6.4 percentage-point increase in the share of new immigrants reduces test scores by about $11 \%$ of the standard deviation. Among policy variables, adaptation of education to student needs has the greatest impact. A one standard deviation improvement in this variable more than offsets a one standard deviation increase in the share of new immigrants. Other policy variables have a relatively small impact. Furthermore, one needs to keep in mind that the impacts of the share of certified teachers and spending per pupil are insignificant when endogeneity is taken into account. The impact of the same variations in policy and socio-economic variables is generally lower in

\footnotetext{
${ }^{12}$ For a recent review, see Smidova $\left(2019_{[30]}\right)$.
} 
the top than in the bottom quartile of the socio-economic distribution of schools (Annex Table 4).

\section{Robustness checks}

Additional regressions have been run to check the robustness of the results. First, equations with only one policy variable at a time are estimated to check the stability of coefficients, which could be affected by interactions between variables. Second, the measure of adaptation of education to student needs is replaced by other survey measures of school quality. Third, the indicator variables for the three main cities are replaced by fixed effects for all municipalities. Fourth, mathematics test scores are replaced by English and Swedish test results. Fifth, the school density indicator is replaced by the share of students attending private schools or by the indicator of distance between schools, as a measure of competition. Sixth, cross-sectional SFA is performed to assess the stability of the model over time. Seventh, alternative SFA models are estimated. These tests largely confirm the robustness of the results.

The policy variables show relatively low bilateral correlations. Nevertheless, they could be subject to multicollinearity, which would affect the precision of the coefficient estimates. To check the stability of the coefficients, equations with only one policy variable at a time are estimated. The coefficients remain broadly unchanged in the main fixed effect model (Annex Table 5) and random effect model (Annex Table 6).

The measure of adaptation of education to student needs is part of a wider survey. As discussed earlier, the score on that particular question was chosen because it was considered the most meaningful and introducing more than one score from the survey was undesirable, as these scores exhibit strong correlation between them. Substituting other scores to adaptation of education to student needs one by one does not materially alter the results. All scores are significant, but have lower coefficients than the original variable (Annex Table 7). In the SFA, average efficiency is roughly equivalent and the correlation between efficiency scores exceeds $97 \%$.

The baseline model includes dummies for the commuting areas centred around Sweden's three main cities. However, as heterogeneity also exists between smaller municipalities, introducing fixed effects for all municipalities is an alternative. This approach is only introduced as a robustness check, as it has some drawbacks. First, there are 286 municipalities in the sample, which potentially creates an incidental parameter problem. Second, spending per pupil needs to be discarded, as it is equal for all schools within a municipality. Third, fixed effects will reflect exogenous factors affecting educational performance, but given the vast responsibilities of municipalities in education, they may also reflect factors related to the management of education. Nevertheless, the model with municipal fixed effects provides a useful robustness check to the baseline results. The coefficients are roughly unchanged for most variables (Annex Table 8). The coefficient of for-profit schools is smaller and only significant at the $10 \%$ level, instead of at the $1 \%$ level. Conversely, the density indicator of competition, which was insignificant, becomes significant at the $10 \%$ level, with a negative sign. In the bottom quartile of the socioeconomic distribution of schools, the results are generally in line with the baseline specification, although the coefficients on for-profit schools and the density of schools become smaller and statistically insignificant. Results in the top quartile are essentially unchanged. Estimates for schools below the median mirror the results from the bottom quartile, with smaller and less significant negative effects from for-profit schools than in the baseline model and insignificant effects from school density. Above the median, the 
coefficient on for-profit schools is reduced and becomes statistically insignificant. Altogether, the municipal fixed effects model supports the robustness of the main results, even though they confirm that caution is warranted in the interpretation of for-profit schools and competition effects.

The regressions so far have used the national mathematics test as the endogenous variable, as it is considered the most reliable measure of education outcomes available. However, the results are mostly robust when the mathematics test score is replaced by Swedish and English reading and listening test scores (Annex Tables 9 and 10), results considered the most objective following mathematics (Vlachos, 2018 $8_{[7]}$ ). Three variables affect test results differently, however. The share of new immigrants improves the Swedish score but with a non-significant coefficient. This seems counterintuitive, but the test scores measured in this study is for students attending ordinary Swedish classes. New immigrants normally attend a separate class, "Swedish for immigrants", and will thus not be part of the sample. Forprofit schools, which performed significantly below average in the mathematics test, do not perform significantly differently in the two other subjects. Also, the competition density indicator becomes insignificant for the English test and significant and positive for the Swedish test.

The lack of a significant negative effect of for-profit schools and competition may mean that the results for the mathematics test cannot be generalised to other subjects, but there are good reasons not to take the results in Swedish and English at face value. The coefficient for the competition indicator in the Swedish test regression is likely affected by the exclusion of new immigrants, a group likely to be among the most negatively affected by school segregation induced by choice and competition. Differences in grade inflation in different areas and school types could also explain why the negative competition effect on mathematics grades is not found in the grades in other subjects. Vlachos $\left(2018_{[7]}\right)$ and Skolinspektionen $\left(2013_{[22]}\right)$ document that for-profit schools give more lenient grades than public schools. Wondratschek, Edmark and Frölich $\left(2013_{[12]}\right)$ show that areas with higher competition also have somewhat higher grade inflation. Grading leniency is higher in subjects where grading depends more on teacher judgment, with the room for judgement lowest in the national test in mathematics, and somewhat more room for judgment in the English and Swedish tests.

Using the share of students attending private schools within a municipality as an alternative competition indicator in the spirit of Böhlmark and Lindahl $\left(2015_{[11]}\right)$ replicates the pattern found with the density indicator of competition. Contrary to the main results, negative competition effects are also significant for the full-sample regression (Annex Tables 11, 12 and 13). The distance indicator of competition yields similar results as the density indicator (Annex Tables 14, 15 and 16).

Cross-sectional SFA is performed to assess the stability of the model over time (Annex Table 17). The coefficients vary from year to year. They are broadly in line with the results of the panel SFA, even though only adaptation of education to student needs, parents' education, the share of new immigrants and the Stockholm dummy are consistently statistically significant over time. Average inefficiency varies from around $7 \%$ to $12 \%$ across years, which is close to the SFA panel results. The correlation of inefficiency scores (linear and rank) across years is in the $30 \%$ to $40 \%$ range. This relatively low correlation justifies the use of the "true" random effect model, which allows efficiency in a given school to vary from year to year.

However, modelling choices, notably regarding the treatment of time-invariant unobserved heterogeneity, affect efficiency scores. The "true" random effect model separates 
inefficiency, which is allowed to vary over time, from time-invariant unobserved heterogeneity. Nevertheless, one could argue that part of the latter reflects inefficiency (Belotti et al., 2013 $\left.3_{[14]}\right)$. Hence, the "true" random effect model may underestimate inefficiency. Another alternative is to impose time-invariant inefficiency, as in Pitt and Lee $\left(1981_{[16]}\right)$ and Battese and Coelli $\left(1988_{[17]}\right)$. None of these alternatives are fully satisfactory a priori (Greene, $2005_{[20]}$ ), and while the cross-sectional SFA results suggest that assuming time variation in efficiency is reasonable, estimating alternative models provides a useful consistency check regarding inefficiency levels. The Pitt and Lee $\left(1981_{[16]}\right)$ and Battese and Coelli $\left(1988_{[17]}\right)$ models yield average efficiency scores of respectively $9.8 \%$ and $8.2 \%$, in the same order of magnitude as the "true" random effect model. The correlation between the efficiency scores of these two models is about 95\% and above $96 \%$ for rank correlations. Correlations with "true" random effects efficiency score are lower (about 40\% and $30 \%$ for ranks), reflecting time variation of efficiency in this model.

\section{Discussion}

The above empirical analysis shows that even though school results are strongly influenced by the socio-economic characteristics of pupils, policy factors play an important role. The adaptation of education to student needs is consistently significant across regressions and its importance is greater for schools where pupils come from less favourable socioeconomic backgrounds. This suggests that schools, and especially those achieving weaker results, have scope to raise their performance by improving the support they provide to struggling students, notably in the form of tutoring and additional teacher help. In addition, school organisation must be seen within the broader education system. More efficient steering from national policies may both help struggling schools to narrow their gap to the efficiency frontier and shift the frontier to a higher level.

Expenditure on education seems to have a more modest effect on school outcomes, even though additional spending per pupil has a greater impact in schools with a less favourable socio-economic student composition. However, the correlation between spending and test scores cannot be interpreted in a causal way, as struggling schools may receive additional funding. This calls for further investigation of funding decisions by municipalities and of the allocation of funds within schools. Lowering the number of pupils per teacher does not significantly affect school performance in this particular regression set-up.

A high share of certified teachers is associated with better results. However, this seems to largely reflect the self-selection of certified teachers into schools with a more favourable socio-economic mix of students. Certified teachers seem to have a greater impact in schools with a less favourable socio-economic composition. Increasing the share of certified teachers in schools facing the toughest challenges may thus improve results. However, this paper cannot draw firm conclusions on the impact of certified teachers on school results, as endogeneity cannot be rejected even in the bottom quartile of the socio-economic distribution. Furthermore, the literature suggests that the share of certified teachers is an imperfect proxy for teacher quality and that investing more in teacher education is likely to lift education quality. Hanushek, Piopiunik and Wiederhold $\left(2018_{[23]}\right)$ show that a one standard deviation increase in teacher cognitive skills, measured through the OECD Programme for the International Assessment of Adult Competencies (PIAAC), is associated with an increase in student performance, measured by PISA scores, of 0.10 to 0.15 standard deviation. Raising the numeracy skills of teachers in Sweden to the highest level in their sample (Finland) would increase student mathematics performance by 0.114 standard deviation. A systematic review of the literature by Coenen et al. (2018 [24] 
suggests that subject-related degrees and knowledge, especially in mathematics and science, are positively related to student performance, but that general teacher certification is not. The lower performance of for-profit private schools compared to public and nonprofit private schools, after controlling for other factors, calls for further investigation. This result is strongest in schools catering to lower socio-economic groups. Private schools adapt education better to pupils' needs on average, which calls for a cautious interpretation. As controls for the socio-economic background of pupils at the school level are relatively crude, one cannot rule out that lower performance results from a higher level of student disadvantage. An analysis at the pupil level would be needed to reach firmer conclusions on the relative performance of for-profit schools.

School competition negatively affects results in schools with the least favourable socioeconomic mix of pupils, although only weakly. This result is opposite to the results found by Wondratschek, Edmark and Frölich (2013 $\left.{ }_{[12]}\right)$, and Böhlmark and Lindahl (2015 $\left.5_{[11]}\right)$. Both these studies analysed older data, ending in 2006 and 2009, respectively. A possible interpretation of this difference is thus that the effects from competition have changed over time. Recent OECD research shows that the impact of school choice on educational performance varies across countries, depending in particular on framework conditions and implementation, school autonomy and policy guidance. The ability of the education system to provide real, relevant and meaningful choice is also essential to ensure equity and narrow between-school variation in performance $($ OECD, 2017 $[25])$. Pupils from more favourable backgrounds utilise school choice to sort to higher-performing schools, while school choice

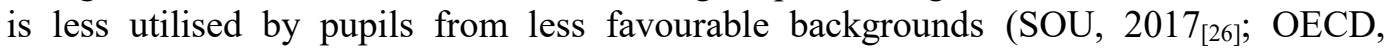
$2018_{[27]}$ ). Lower-achieving students in Sweden lose more than higher-achievers gain from school and classroom segregation (Sund, 2009[28]). These asymmetric peer effects combined with increasing school segregation could turn the previous positive effect from school competition negative. This interpretation is strengthened by consistent results across different competition indicators. However, robustness checks on Swedish and English grades show positive and insignificant effects of competition, respectively. These differences in results across subjects might result from grading leniency in geographical areas of high competition, and the selection of students taking the national test in Swedish. However, these checks could also mean that the results are not valid outside of the data sample, and more research is warranted to draw firm conclusions.

The average level of inefficiency is about $10 \%$, implying that schools could increase their average mathematics test score by on average 10/\% for a given level of inputs. The distribution is relatively narrow. Less than a tenth of the observed inefficiency scores are greater than one standard deviation in test scores. Even though relatively few schools have low efficiency, the consequences for their pupils can be serious, and low scores may represent a potential to improve results by moving closer to the efficient frontier. Average efficiency levels are fairly close across models. Nevertheless, efficiency scores depend on modelling assumptions, notably regarding time variation in efficiency. Furthermore, test scores are imperfect measures of educational outcomes. Hence, estimates of school inefficiency should be interpreted with caution and further research on their causes is needed. 


\section{References}

Andersson, C. and N. Waldenström (2007), "Teacher certification and student achievement in Swedish compulsory schools", http://www.ifau.se.

Battese, G. and T. Coelli (1995), "A model for technical inefficiency effects in a stochastic frontier production function for panel data", Empirical Economics, http://dx.doi.org/10.1007/BF01205442.

Battese, G. and T. Coelli (1988), "Prediction of firm-level technical efficiencies with a generalized frontier production function and panel data", Journal of Econometrics, http://dx.doi.org/10.1016/0304-4076(88)90053-X.

Bell, A. and K. Jones (2015), "Explaining fixed effects: random effects modeling of time-series cross-sectional and panel data", Political Science Research and Methods, http://dx.doi.org/10.1017/psrm.2014.7.

Belotti, F. et al. (2013), "Stochastic frontier analysis using Stata", The Stata Journal, Vol. 13/4, https://www.stata-journal.com/article.html?article=st0315 (accessed on 31 August 2018).

Björklund, A. and K. Salvanes (2011), Education and Family Background: Mechanisms and Policies, Elsevier, http://dx.doi.org/10.1016/S0169-7218(11)03003-6.

Böhlmark, A. and M. Lindahl (2015), "Independent schools and long-run educational outcomes: evidence from Sweden's large-scale voucher reform”, Economica, Vol. 82/327, pp. 508-551, http://dx.doi.org/10.1111/ecca.12130.

Coenen, J. et al. (2018), "Teacher characteristics and their effects on student test scores: a systematic review", Journal of Economic Surveys, Vol. 32/3, pp. 848-877, http://dx.doi.org/10.1111/joes.12210.

Greene, W. (2005), "Reconsidering heterogeneity in panel data estimators of the stochastic frontier model", Journal of Econometrics, http://dx.doi.org/10.1016/j.jeconom.2004.05.003.

Hanushek, E., M. Piopiunik and S. Wiederhold (2018), "The Value of Smarter Teachers: International Evidence on Teacher Cognitive Skills and Student Performance", Journal of Human Resources, pp. 0317-8619R1, http://dx.doi.org/10.3368/jhr.55.1.0317.8619R1.

Misra, K., P. Grimes and K. Rogers (2012), "Does competition improve public school efficiency? A spatial analysis", Economics of Education Review, http://dx.doi.org/10.1016/j.econedurev.2012.08.001.

OECD (2018), Equity in education : breaking down barriers to social mobility, OECD Publishing.

OECD (2017), School choice and school vouchers: An OECD perspective, OECD Publishing, Paris. 
OECD (2015), Improving schools in Sweden: an OECD perspective,

http://www.oecd.org/education/school/Improving-Schools-in-Sweden.pdf (accessed on

2 May 2018).

OECD (2015), OECD Economic Surveys: Sweden 2015, OECD Publishing, Paris, http://dx.doi.org/10.1787/eco surveys-swe-2015-en.

Pareliussen, J., C. André and H. Hwang (2019), "Improving school results and equity in compulsory education in Sweden", OECD Economics Department Working Papers, No. XXX.

Pitt, M. and L. Lee (1981), "The measurement and sources of technical inefficiency in the Indonesian weaving industry", Journal of Development Economics, http://dx.doi.org/10.1016/0304-3878(81)90004-3.

Schmidt, P. and R. Sickles (1984), "Production frontiers and panel data", Journal of Business and Economic Statistics, http://dx.doi.org/10.1080/07350015.1984.10509410.

Skolinspektionen (2013), Olikheterna är för stora (Inequalities are too high), Swedish Schools Inspectorate, Stockholm, https://www.ne.su.se/polopoly fs/1.214664.1418634275!/menu/standard/file/omrattningnationella-prov-2013-resultatbilaga.pdf (accessed on 8 November 2018).

Smidova, Z. (2019), "Drivers of education outcomes: A literature review from a macroeconomic perspective", OECD Economics Department Working Papers, forthcoming, OECD Publishing, Paris.

SOU (2017), Samling för skolan - Nationell strategi för kunskap och likvärdighet (Together for schools - National strategy for knowledge and equality), http://www.regeringen.se/498092/contentassets/e94a1c61289142bfbcfdf54a44377507/samlin g-for-skolan---nationell-strategi-for-kunskap-och-likvardighet-sou-201735.pdf (accessed on 2 May 2018).

Statistics Sweden (2018), Djupdykning i statistik om Sveriges kommuner (Deep-dive in statistics about Sweden's municipalities), https://www.scb.se/hitta-statistik/sverige-isiffror/djupdykning-i-kommunstatistik/ (accessed on 31 August 2018).

Statistics Sweden (2018), Lokala arbetsmarknader (Local labour market regions), https://www.scb.se/hitta-statistik/statistik-efter-amne/arbetsmarknad/sysselsattningforvarvsarbete-och-arbetstider/registerbaserad-arbetsmarknadsstatistikrams/produktrelaterat/Fordjupad-information/lokala-arbetsmarknader-la// (accessed on 30 August 2018).

Sund, K. (2009), "Estimating peer effects in Swedish high school using school, teacher, and student fixed effects", Economics of Education Review, Vol. 28/3, pp. 329-336, http://dx.doi.org/10.1016/J.ECONEDUREV.2008.04.003.

Swedish Agency for Education (2018), SIRIS/SALSA database, https://www.skolverket.se/skolutveckling/statistik/sok-statistik-om-forskola-skola-ochvuxenutbildning (accessed on 31 August 2018). 
Swedish School Inspectorate (2018), Statistik från Skolenkäten (Statistics from the Student Satisfaction Survey), https://www.skolinspektionen.se/sv/Statistik/statistik-fran-skolenkaten/ (accessed on 31 August 2018).

Swedish School Inspectorate (2013), Olikheterna är för stora, Omrättning av nationella prov $i$ grundskolan och gymnasieskolan, 2013 (Differences are too big, re-grading of national tests in compulsory and upper secondary schools, 2013), https://www.skolinspektionen.se/globalassets/publikationssok/granskningsrapporter/omrattni ng/2013/omrattning-nationella-prov-2013.pdf (accessed on 31 August 2018).

Vlachos, J. (2018), “Trust-based evaluation in a market-oriented school system”, No. 1217, IFN, Stockholm, https://www.ifn.se/publikationer/working papers/2018/1217 (accessed on 5 June 2018).

Weber, S. and M. Péclat (2016), “A simple command to calculate travel distance and travel time",

https://www.unine.ch/files/live/sites/irene/files/shared/documents/Publications/Working\%20p apers/2016/WP_16-10.pdf (accessed on 3 May 2018).

Wondratschek, V., K. Edmark and M. Frölich (2013), The short-and long-term effects of school choice on student outcomes-Evidence from a school choice reform in Sweden, https://www.jstor.org/stable/pdf/23646327.pdf?refreqid=excelsior\%3Aa335cb8a84f37e0896b 58a9b1018c305 (accessed on 31 August 2018). 
Annex A. Tables

\begin{tabular}{|c|c|c|c|c|c|c|c|c|c|c|c|c|c|c|c|}
\hline Model type & $\mathrm{FE}[1]$ & $\mathrm{RE}[2]$ & $\mathrm{FE}[3]$ & $\mathrm{RE}[4]$ & $\mathrm{RE}[5]$ & $\mathrm{RE}[6]$ & RE[7] & $\mathrm{RE}[8]$ & REWB[9] & $\begin{array}{c}\text { RE[10] } \\
\text { Endogenous } \\
\text { share of } \\
\text { certified } \\
\text { teachers }^{2}\end{array}$ & $\begin{array}{c}\text { RE[11] } \\
\text { Endogenous } \\
\text { spending } \\
\text { per pupil }{ }^{3}\end{array}$ & $\mathrm{RE}[12]$ & REWB[13] & $\mathrm{RE}[14]$ & REWB[15] ${ }^{1}$ \\
\hline \multicolumn{16}{|l|}{ Policy variables } \\
\hline $\begin{array}{l}\text { Spending per } \\
\text { pupil }\end{array}$ & 0.061 & $0.075^{* \star}$ & $0.078^{*}$ & $0.093^{* \star *}$ & $0.065^{* *}$ & $0.065^{\star *}$ & $0.077^{* \star *}$ & $0.091^{\star * \star}$ & $\begin{array}{l}0.090^{* *} / \\
0.100^{* *}\end{array}$ & $0.101^{* * *}$ & 0.006 & & & & \\
\hline $\begin{array}{l}\text { Pupils } \quad \text { per } \\
\text { teacher }\end{array}$ & -0.002 & $0.005^{\star \star *}$ & -0.002 & -0.000 & -0.001 & -0.001 & -0.001 & -0.000 & $\begin{array}{l}-0.001 / \\
-0.001\end{array}$ & -0.000 & -0.001 & -0.000 & $\begin{array}{l}-0.001 / \\
-0.000\end{array}$ & & \\
\hline $\begin{array}{l}\text { Share of certified } \\
\text { teachers }\end{array}$ & $0.088^{* \star *}$ & $0.102^{* * \star}$ & $0.092^{* * *}$ & $0.078^{* * *}$ & $0.085^{* * *}$ & $0.083^{* * *}$ & $0.078^{\star \star *}$ & $0.080^{* * *}$ & $\begin{array}{c}0.100^{* * *} / \\
0.039^{* *}\end{array}$ & -0.131 & $0.064^{* * *}$ & & & & \\
\hline $\begin{array}{l}\text { Adaptation to } \\
\text { student needs }\end{array}$ & & & & & & & $0.047^{\star \star *}$ & $0.050^{\star \star \star}$ & $0.046^{\star \star \star}$ & $0.055^{\star \star \star}$ & $0.048^{* * *}$ & $0.054^{* * *}$ & $0.049^{* * *}$ & & \\
\hline \multicolumn{16}{|l|}{ School type } \\
\hline For-profit & & & & & & -0.012 & $-0.024^{* \star *}$ & $-0.028^{* \star *}$ & $-0.039^{* * *}$ & $-0.050^{\star * \star}$ & $-0.029^{* * *}$ & $-0.029^{\star * \star}$ & $-0.037^{\star \star *}$ & $-0.016^{*}$ & $-0.026^{\star \star \star}$ \\
\hline Non-profit & & & & & & 0.022 & 0.001 & 0.006 & -0.012 & -0.010 & 0.002 & -0.020 & $-0.035^{\star *}$ & -0.001 & -0.020 \\
\hline \multicolumn{16}{|l|}{ Year } \\
\hline 2014 & $-0.070^{\star \star \star}$ & $-0.072^{\star \star \star}$ & $-0.074^{\star \star *}$ & $-0.075^{\star \star \star}$ & $-0.074^{\star \star \star}$ & $-0.0744^{* \star \star}$ & $-0.075^{\star \star *}$ & $-0.071^{\star \star \star}$ & $-0.070^{\star \star \star}$ & $-0.072^{\star \star \star}$ & $-0.069^{\star \star \star}$ & $-0.069^{\star \star \star}$ & $-0.068^{\star \star *}$ & $-0.069^{\star \star *}$ & $-0.067^{\star \star \star}$ \\
\hline 2015 & $-0.137^{\star \star \star}$ & $-0.138^{\star \star *}$ & $-0.135^{\star * *}$ & $-0.136^{\star \star *}$ & $-0.134^{\star * \star}$ & $-0.134^{\star * *}$ & $-0.135^{\star \star *}$ & $-0.129^{\star \star \star}$ & $-0.128^{\star * *}$ & $-0.141^{\star \star \star}$ & $-0.125^{\star \star \star}$ & $-0.129^{\star \star \star}$ & $-0.129^{* * *}$ & $-0.129^{\star \star *}$ & $-0.129^{\star \star \star}$ \\
\hline 2016 & $-0.012^{*}$ & $-0.016^{* \star *}$ & $-0.014^{* *}$ & $-0.017^{* \star *}$ & $-0.014^{* * *}$ & $-0.014^{* * *}$ & $-0.014^{* \star *}$ & $-0.014^{* *}$ & $-0.013^{* *}$ & -0.004 & -0.007 & -0.002 & -0.00061 & -0.003 & -0.001 \\
\hline 2017 & $-0.142^{\star \star \star}$ & $-0.146^{\star \star \star}$ & $-0.140^{\star \star \star}$ & $-0.144^{\star \star \star}$ & $-0.140^{\star \star *}$ & $-0.140^{* \star *}$ & $-0.140^{* \star *}$ & $-0.135^{\star \star \star}$ & $-0.134^{\star \star *}$ & $-0.129^{\star \star \star}$ & $-0.123^{\star \star \star}$ & $-0.118^{\star \star \star}$ & $-0.117^{\star \star *}$ & $-0.118^{\star \star \star}$ & $-0.116^{\star \star \star}$ \\
\hline \multicolumn{16}{|l|}{$\begin{array}{l}\text { Socio-economic } \\
\text { variables }\end{array}$} \\
\hline $\begin{array}{l}\text { Share of new } \\
\text { immigrants }\end{array}$ & & & $-0.239^{* \star *}$ & $-0.255^{\star \star \star}$ & $-0.255^{\star \star \star}$ & $-0.261^{\star \star *}$ & $-0.268^{\star \star \star}$ & $-0.308^{\star \star \star}$ & $\begin{array}{l}-0.269^{* * *} / \\
-0.308^{* * *}\end{array}$ & $-0.338^{\star \star \star}$ & $-0.309^{\star \star \star}$ & $-0.314^{\star \star *}$ & $\begin{array}{l}-0.277^{* \star *} \\
-0.283^{* \star *}\end{array}$ & $-0.305^{\star * *}$ & $\begin{array}{l}-0.277^{* * *} \mid \\
-0.239^{* * *}\end{array}$ \\
\hline Share of boys & & & $-0.051^{\text {** }}$ & $-0.049^{* *}$ & $-0.049^{* \star}$ & $-0.048^{\star *}$ & $-0.050^{* *}$ & $-0.060^{* *}$ & $\begin{array}{c}-0.056^{\star \star /} \\
-0.082\end{array}$ & $-0.056^{* *}$ & $-0.061^{* *}$ & $-0.055^{\star *}$ & $\begin{array}{l}-0.051^{*} / \\
-0.077\end{array}$ & $-0.056^{\star \star}$ & $\begin{array}{l}-0.052^{*} / \\
-0.074\end{array}$ \\
\hline Parents' & & & $0.339^{\star \star \star}$ & $0.467^{\star \star *}$ & $0.460^{\star \star \star}$ & $0.461^{* * *}$ & $0.447^{\star \star \star}$ & $0.442^{\star * \star}$ & $0.334^{\star \star *} \mid$ & $0.469^{\star * \star}$ & $0.468^{\star \star \star}$ & $0.443^{* \star \star}$ & $0.323^{\star \star *} /$ & $0.461^{\star * \star}$ & $0.323^{\star \star \star} I$ \\
\hline
\end{tabular}




\begin{tabular}{|c|c|c|c|c|c|c|c|c|c|c|c|c|c|c|c|}
\hline education & & & & & & & & & $0.505^{* * *}$ & & & & $0.508^{* * *}$ & & $0.540^{* \star *}$ \\
\hline \multicolumn{16}{|l|}{ Municipality } \\
\hline Stockholm & & & & & $0.042^{* \star *}$ & $0.042^{* * *}$ & $0.045^{* \star *}$ & $0.050^{* * *}$ & $0.046^{* \star *}$ & $0.034^{* * *}$ & $0.0505^{* \star *}$ & $0.047^{* * *}$ & $0.045^{* * *}$ & $0.042^{* * *}$ & $0.040^{* * *}$ \\
\hline Gothenburg & & & & & $0.023^{\star \star *}$ & $0.022^{\star \star *}$ & $0.023^{\star \star \star}$ & $0.026^{\star \star *}$ & $0.022^{\star \star}$ & $0.022^{* *}$ & $0.0241^{* * *}$ & $0.024^{\star \star \star}$ & $0.020^{* *}$ & $0.023^{\star * *}$ & $0.019^{* *}$ \\
\hline Malmö & & & & & $0.026^{\star \star *}$ & $0.026^{\star \star \star}$ & $0.027^{\star \star \star}$ & $0.035^{\star \star \star}$ & $0.033^{\star \star \star}$ & $0.029^{\star \star *}$ & $0.0321^{* * *}$ & $0.030^{\star \star \star}$ & $0.029^{\star \star *}$ & $0.028^{\star \star \star}$ & $0.028^{\star \star \star}$ \\
\hline \multicolumn{16}{|l|}{ Competition } \\
\hline Density & & & & & & & & -0.005 & -0.007 & -0.005 & -0.003 & -0.001 & -0.003 & -0.002 & -0.003 \\
\hline Constant & $1.756^{\star \star \star}$ & $1.498^{\star * *}$ & 0.820 & 0.351 & $0.679^{* \star}$ & $0.676^{* *}$ & 0.255 & 0.077 & -0.089 & 0.032 & 1.023 & $1.143^{* * *}$ & $1.041^{* * *}$ & $1.470^{\star * *}$ & $1.302^{\star * \star}$ \\
\hline \multicolumn{16}{|l|}{ Sample } \\
\hline Observations & 5720 & 5720 & 5720 & 5720 & 5720 & 5720 & 5720 & 4878 & 4878 & 4878 & 4878 & 5011 & 5011 & 5030 & 5030 \\
\hline Schools & 1346 & 1346 & 1346 & 1346 & 1346 & 1346 & 1346 & 1140 & 1140 & 1140 & 1140 & 1183 & 1183 & 1183 & 1183 \\
\hline \multicolumn{16}{|l|}{$\mathbf{R}^{2}$} \\
\hline Overall & 0.092 & 0.124 & 0.471 & 0.489 & 0.496 & 0.496 & 0.510 & 0.521 & 0.526 & 0.488 & 0.521 & 0.515 & 0.520 & 0.497 & 0.503 \\
\hline Within & 0.253 & 0.248 & 0.305 & 0.299 & 0.300 & 0.300 & 0.301 & 0.287 & 0.291 & 0.254 & 0.284 & 0.277 & 0.282 & 0.274 & 0.279 \\
\hline Between & 0.016 & 0.065 & 0.541 & 0.554 & 0.561 & 0.563 & 0.580 & 0.598 & 0.604 & 0.566 & 0.599 & 0.594 & 0.598 & 0.574 & 0.577 \\
\hline
\end{tabular}

***,** and * indicate significance at respectively the $1 \%, 5 \%$ and $10 \%$ level. Robust standard errors (clustered) are used.

1. The random effects within-between model (REWB) allows between and within school coefficients to differ (Bell and Jones, 2015). The first number

shows the within coefficient and the second the between coefficient. Only one coefficient is estimated for variables without time variation.

2. Uses the share of female teachers as an instrument for the share of certified teachers.

3. Uses the young age dependency ratio as an instrument. 
Annex Table 2. Panel regressions on sub-samples

\begin{tabular}{|c|c|c|c|c|c|c|c|c|}
\hline Model type & $\begin{array}{c}\text { RE[1] } \\
\text { Bottom } \\
\text { quartile } \\
\text { soc_stat }{ }^{1}\end{array}$ & $\begin{array}{c}\text { RE[2] } \\
\text { Top } \\
\text { quartile } \\
\text { soc_stat }{ }^{1}\end{array}$ & $\begin{array}{c}\text { RE[3] } \\
\text { Below } \\
\text { median } \\
\text { soc_stat }{ }^{1}\end{array}$ & $\begin{array}{c}\text { RE[4] } \\
\text { Above } \\
\text { median } \\
\text { soc_stat }{ }^{1}\end{array}$ & $\begin{array}{c}\text { RE[5] } \\
\text { Bottom } \\
\text { quartile } \\
\text { soc_stat }{ }^{2}\end{array}$ & $\begin{array}{c}\text { RE[6] } \\
\text { Top } \\
\text { quartile } \\
\text { soc_stat }{ }^{2}\end{array}$ & $\begin{array}{c}\text { RE[7] } \\
\text { Below } \\
\text { median } \\
\text { soc_stat }{ }^{2}\end{array}$ & $\begin{array}{c}\text { RE[8] } \\
\text { Above } \\
\text { median } \\
\text { soc_stat }{ }^{2}\end{array}$ \\
\hline \multicolumn{9}{|l|}{ Policy variables } \\
\hline Spending per pupil & $0.180^{* *}$ & 0.047 & $0.088^{*}$ & $0.068^{*}$ & $0.134^{*}$ & 0.035 & $0.131^{* *}$ & 0.048 \\
\hline Pupils per teacher & -0.000 & 0.002 & -0.001 & 0.001 & -0.000 & 0.002 & -0.001 & -0.000 \\
\hline $\begin{array}{l}\text { Share of certified } \\
\text { teachers }\end{array}$ & $0.112^{\star * \star}$ & 0.022 & $0.076^{* * *}$ & $0.079^{* \star *}$ & $0.137^{* \star *}$ & 0.008 & $0.082^{* * *}$ & $0.076^{* * *}$ \\
\hline $\begin{array}{l}\text { Adaptation to student } \\
\text { needs }\end{array}$ & $0.056^{* * *}$ & $0.035^{\star * *}$ & $0.051^{* * *}$ & $0.052^{* * *}$ & $0.076^{* * *}$ & $0.032^{* * *}$ & $0.054^{* * *}$ & $0.047^{* * *}$ \\
\hline \multicolumn{9}{|l|}{ School type } \\
\hline For-profit & $-0.049^{*}$ & -0.012 & $-0.058^{\star \star *}$ & $-0.021^{* *}$ & -0.029 & -0.006 & $-0.049^{\star *}$ & $-0.022^{\star *}$ \\
\hline Non-profit & $0.191^{* *}$ & 0.006 & $0.091^{* *}$ & -0.009 & $0.290^{\star * *}$ & 0.008 & $0.100^{*}$ & -0.008 \\
\hline \multicolumn{9}{|l|}{ Year } \\
\hline 2014 & $-0.079^{* * *}$ & $-0.074^{\star * *}$ & $-0.071^{* * *}$ & $-0.071^{* * *}$ & $-0.082^{* * *}$ & $-0.069^{* * *}$ & $-0.075^{\star * *}$ & $-0.066^{* * *}$ \\
\hline 2015 & $-0.155^{\star \star *}$ & $-0.097^{\star * *}$ & $-0.149^{* * *}$ & $-0.110^{* * *}$ & $-0.164^{* * *}$ & $-0.097^{\star * *}$ & $-0.149^{* * *}$ & $-0.110^{* * *}$ \\
\hline 2016 & 0.012 & $-0.041^{* * *}$ & 0.008 & $-0.032^{* * *}$ & 0.010 & $-0.035^{\star * *}$ & 0.004 & $-0.028^{* * *}$ \\
\hline 2017 & $-0.179^{\star \star \star}$ & $-0.097^{\star \star *}$ & $-0.155^{\star \star \star}$ & $-0.114^{\star \star *}$ & $-0.170^{* * *}$ & $-0.089^{\star * *}$ & $-0.160^{\star \star *}$ & $-0.111^{* * *}$ \\
\hline \multicolumn{9}{|l|}{$\begin{array}{l}\text { Socio-economic } \\
\text { variables }\end{array}$} \\
\hline Share of new immigrants & $-0.407^{* * *}$ & $-0.263^{* *}$ & $-0.308^{* * *}$ & $-0.209^{* *}$ & $-0.367^{* * *}$ & $-0.304^{* * *}$ & $-0.308^{* * *}$ & $-0.212^{* * *}$ \\
\hline Share of boys & $-0.146^{\star *}$ & $-0.048^{*}$ & $-0.075^{\star}$ & $-0.042^{*}$ & $-0.114^{*}$ & -0.039 & $-0.079^{* *}$ & $-0.038^{*}$ \\
\hline Parents' education & $0.461^{* * *}$ & $0.391^{* * *}$ & $0.442^{* * *}$ & $0.440^{\star * *}$ & $0.394^{* * *}$ & $0.388^{* * *}$ & $0.408^{* * *}$ & $0.425^{\star * *}$ \\
\hline \multicolumn{9}{|l|}{ Municipality } \\
\hline Stockholm & 0.008 & $0.079^{* * *}$ & $0.025^{\star *}$ & $0.072^{* * *}$ & 0.022 & $0.077^{* * *}$ & 0.018 & $0.082^{* * *}$ \\
\hline Gothenburg & 0.015 & $0.041^{* * *}$ & $0.033^{* *}$ & $0.033^{* * *}$ & 0.020 & $0.042^{* * *}$ & 0.021 & $0.039^{* * *}$ \\
\hline Malmö & 0.022 & $0.051^{* * *}$ & $0.028^{*}$ & $0.054^{* * *}$ & 0.018 & $0.050^{* * *}$ & 0.015 & $0.062^{* * *}$ \\
\hline \multicolumn{9}{|l|}{ Competition } \\
\hline Density & $-0.025^{\star *}$ & 0.002 & $-0.013^{* *}$ & -0.003 & $-0.028^{* * *}$ & 0.001 & $-0.015^{* *}$ & -0.003 \\
\hline Constant & -0.951 & $0.797^{\star}$ & 0.147 & 0.289 & -0.465 & $0.973^{\star *}$ & -0.297 & 0.604 \\
\hline \multicolumn{9}{|l|}{ Sample } \\
\hline Observations & 1146 & 1302 & 2325 & 2553 & 1140 & 1301 & 2310 & 2568 \\
\hline Schools & 450 & 414 & 719 & 735 & 281 & 292 & 552 & 588 \\
\hline \multicolumn{9}{|l|}{$\mathbf{R}^{2}$} \\
\hline Overall & 0.330 & 0.416 & 0.326 & 0.465 & 0.361 & 0.433 & 0.339 & 0.470 \\
\hline Within & 0.316 & 0.247 & 0.297 & 0.290 & 0.305 & 0.277 & 0.306 & 0.302 \\
\hline Between & 0.263 & 0.428 & 0.328 & 0.469 & 0.387 & 0.497 & 0.353 & 0.502 \\
\hline
\end{tabular}

$* * *, * *$ and $*$ indicate significance at respectively the $1 \%, 5 \%$ and $10 \%$ level. Robust standard errors (clustered) are used.

1. Quartiles and median are calculated after sorting schools according to socio-economic chararcteristics of their students.

2. Quartiles and median are calculated after sorting schools according to their average socio-economic characteristics index over 2013-2017. 
Annex Table 3. Stochastic frontier analysis

\begin{tabular}{|c|c|c|c|c|c|}
\hline Model type & $\begin{array}{c}\text { SFA } \\
{[1]} \\
\text { Exponential }\end{array}$ & $\begin{array}{c}\text { SFA } \\
{[2]} \\
\text { Half-normal }\end{array}$ & $\begin{array}{c}\text { SFA REWB }{ }^{1} \\
{[3]} \\
\text { Exponential }\end{array}$ & $\begin{array}{c}\text { SFA } \\
{[4]} \\
\text { Exponential }\end{array}$ & $\begin{array}{c}\text { SFA REWB }{ }^{1} \\
{[5]} \\
\text { Exponential }\end{array}$ \\
\hline \multicolumn{6}{|l|}{ Policy variables } \\
\hline Spending per pupil & $0.063^{* * *}$ & $0.074^{* * *}$ & $0.058 * / 0.071^{* *}$ & & \\
\hline Pupils per teacher & -0.001 & -0.001 & $-0.001 /-0.002$ & -0.001 & $-0.001 /-0.001$ \\
\hline Share of certified teachers & $0.046^{* * *}$ & $0.053^{* * *}$ & $0.058^{* * *} / 0.025$ & & \\
\hline Adaptation to student needs & $0.040^{\star * *}$ & $0.042^{* * *}$ & $0.038^{* * *}$ & $0.042^{* \star *}$ & $0.040^{* * *}$ \\
\hline \multicolumn{6}{|l|}{ School type } \\
\hline For-profit & -0.000 & -0.006 & -0.007 & -0.001 & -0.005 \\
\hline Non-profit & 0.024 & 0.023 & 0.016 & 0.006 & -0.001 \\
\hline \multicolumn{6}{|l|}{ Year } \\
\hline 2014 & $-0.070^{* * *}$ & $-0.069^{* * *}$ & $-0.070^{* * *}$ & $-0.069^{* * *}$ & $-0.068^{* * *}$ \\
\hline 2015 & $-0.104^{* * *}$ & $-0.106^{* * *}$ & $-0.104^{* * *}$ & $-0.103^{* * *}$ & $-0.103^{* * *}$ \\
\hline 2016 & $-0.020^{* * *}$ & $-0.019^{* * *}$ & $-0.019^{* * *}$ & $-0.013^{* * *}$ & $-0.012^{* * *}$ \\
\hline 2017 & $-0.111^{* * *}$ & $-0.115^{\star * *}$ & $-0.112^{\star \star *}$ & $-0.101^{* * *}$ & $-0.101^{* * *}$ \\
\hline \multicolumn{6}{|l|}{ Municipality } \\
\hline Stockholm & $0.048^{* * *}$ & $0.049^{* * *}$ & $0.048^{* \star *}$ & $0.048^{* \star *}$ & $0.048^{* * *}$ \\
\hline Gothenburg & $0.027^{* \star *}$ & $0.027^{\star * *}$ & $0.024^{* * *}$ & $0.024^{* \star *}$ & $0.022^{* * *}$ \\
\hline Malmö & $0.039^{* * *}$ & $0.039^{* * *}$ & $0.038^{* * *}$ & $0.033^{* * *}$ & $0.033^{* * *}$ \\
\hline \multicolumn{6}{|l|}{ Socio-economic variables } \\
\hline Share of new immigrants & $-0.247^{* * *}$ & $-0.250^{\star * *}$ & $\begin{array}{c}-0.191^{* * *} /- \\
0.311^{* * *}\end{array}$ & $-0.244^{* * *}$ & $-0.196^{* * *}$ \\
\hline Share of boys & $-0.049^{* *}$ & $-0.049^{* *}$ & $-0.054^{\star *} /-0.031$ & $-0.041^{* *}$ & $-0.048^{* *}$ \\
\hline Parents' education & $0.371^{* * *}$ & $0.382^{* * *}$ & $0.310^{\star \star *} / 0.402^{\star \star *}$ & $0.372^{\star \star *}$ & $0.301^{* * *}$ \\
\hline \multicolumn{6}{|l|}{ Competition } \\
\hline Density & -0.002 & -0.004 & -0.002 & 0.002 & $-0.269^{* * *}$ \\
\hline Constant & $0.737^{* * *}$ & $0.606^{\star *}$ & 0.621 & $1.463^{\star * *}$ & -0.011 \\
\hline Lambda $^{2}$ & $1.79^{* * *}$ & $3.97^{\star * \star}$ & $1.75^{\star * *}$ & $1.83^{* * *}$ & $1.80^{\star * *}$ \\
\hline Average inefficiency (\%) & 9.2 & 12.3 & 9.10 & 9.24 & 9.17 \\
\hline \multicolumn{6}{|l|}{ Sample } \\
\hline Observations & 4878 & 4878 & 4878 & 5011 & 5011 \\
\hline Schools & 1140 & 1140 & 1140 & 1183 & 1183 \\
\hline
\end{tabular}

$* * *, * *$ and $*$ indicate significance at respectively the $1 \%, 5 \%$ and $10 \%$ level. Robust standard errors (clustered) are used.

1. The random effects within-between model (REWB) allows between and within school coefficients to differ (Bell and Jones, 2015). The first number shows the within coefficient and the second the between coefficient. Only one coefficient is estimated for variables without time variation.

2. Lambda is the ratio of the variances of the asymmetric and symmetric errors. 
Annex Table 4. Impact of changes in exogenous variables

\begin{tabular}{|c|c|c|c|c|c|}
\hline & \multirow{2}{*}{ Mean } & \multirow{2}{*}{$\begin{array}{c}\text { Standard } \\
\text { deviation (sd) }\end{array}$} & \multirow{2}{*}{$\begin{array}{l}\text { Semi- } \\
\text { elasticity }{ }^{1}\end{array}$} & \multicolumn{2}{|c|}{$\begin{array}{l}\text { Impact of one full sample } \\
\text { sd change }\end{array}$} \\
\hline & & & & $\%$ of test score & $\begin{array}{l}\text { In sd of test } \\
\text { scores }\end{array}$ \\
\hline \multicolumn{6}{|l|}{ Whole sample } \\
\hline Mathematics test score & 11.546 & 2.112 & .. & & \\
\hline \multicolumn{6}{|l|}{ Policy variables } \\
\hline Spending per pupil (SEK) & 96555 & 10220 & 0.091 & 0.967 & 0.053 \\
\hline Pupils per teacher & 12.610 & 2.411 & 0.000 & -0.043 & -0.002 \\
\hline Share of certified teachers (\%) & 72.113 & 20.453 & 0.080 & 1.626 & 0.089 \\
\hline Adaptation to student needs & 6.933 & 0.556 & 0.050 & 2.755 & 0.151 \\
\hline \multicolumn{6}{|l|}{ Socio-economic variables } \\
\hline Share of new immigrants (\%) & 4.383 & 6.424 & -0.308 & -1.979 & -0.108 \\
\hline Share of boys (\%) & 51.836 & 8.992 & -0.060 & -0.536 & -0.029 \\
\hline Parent education level (index) ${ }^{2}$ & 2.275 & 0.233 & 0.442 & 10.290 & 0.563 \\
\hline \multicolumn{6}{|l|}{ School-type } \\
\hline For-profit & 0.199 & 0.400 & -0.028 & -1.099 & -0.060 \\
\hline Non-profit & 0.035 & 0.183 & 0.006 & 0.108 & 0.006 \\
\hline \multicolumn{6}{|l|}{ Municipality } \\
\hline Stockholm & 0.286 & 0.452 & 0.050 & 2.243 & 0.123 \\
\hline Gothenburg & 0.127 & 0.333 & 0.026 & 0.855 & 0.047 \\
\hline Malmö & 0.137 & 0.344 & 0.035 & 1.197 & 0.065 \\
\hline \multicolumn{6}{|l|}{ Competition } \\
\hline Density & 0.752 & 1.000 & -0.005 & -0.538 & -0.029 \\
\hline \multicolumn{6}{|l|}{ Bottom quartile } \\
\hline Mathematics test score & 9.872 & 1.914 & .. & & \\
\hline \multicolumn{6}{|l|}{ Policy variables } \\
\hline Spending per pupil (SEK) & 98110 & 10305 & 0.180 & 1.875 & 0.102 \\
\hline Pupils per teacher & 11.614 & 2.319 & 0.000 & -0.025 & -0.001 \\
\hline Share of certified teachers (\%) & 69.771 & 19.996 & 0.112 & 2.291 & 0.125 \\
\hline Adaptation to student needs & 6.779 & 0.525 & 0.056 & 3.105 & 0.170 \\
\hline \multicolumn{6}{|l|}{ Socio-economic variables } \\
\hline Share of new immigrants (\%) & 11.334 & 8.396 & -0.407 & -2.615 & -0.143 \\
\hline Share of boys (\%) & 53.842 & 8.786 & -0.146 & -1.313 & -0.072 \\
\hline Parent education level (index) ${ }^{2}$ & 1.997 & 0.143 & 0.461 & 10.733 & 0.587 \\
\hline \multicolumn{6}{|l|}{ School-type } \\
\hline For-profit & 0.056 & 0.230 & -0.049 & -1.970 & -0.108 \\
\hline Non-profit & 0.006 & 0.078 & 0.191 & 3.503 & 0.192 \\
\hline \multicolumn{6}{|l|}{ Municipality } \\
\hline Stockholm & 0.298 & 0.458 & 0.008 & 0.350 & 0.019 \\
\hline Gothenburg & 0.071 & 0.256 & 0.015 & 0.512 & 0.028 \\
\hline Malmo & 0.140 & 0.348 & 0.022 & 0.757 & 0.041 \\
\hline
\end{tabular}




\section{Competition}

\begin{tabular}{|c|c|c|c|c|c|}
\hline Density & 0.673 & 0.856 & -0.025 & -2.480 & -0.136 \\
\hline \multicolumn{6}{|l|}{ Top quartile } \\
\hline Mathematics test score & 13.429 & 1.574 & .. & & \\
\hline \multicolumn{6}{|l|}{ Policy variables } \\
\hline Spending per pupil (SEK) & 97420 & 10936 & 0.047 & 0.491 & 0.027 \\
\hline Pupils per teacher & 13.609 & 2.334 & 0.002 & 0.528 & 0.029 \\
\hline Share of certified teachers (\%) & 75.479 & 20.715 & 0.022 & 0.454 & 0.025 \\
\hline Adaptation to student needs & 7.161 & 0.560 & 0.035 & 1.944 & 0.106 \\
\hline \multicolumn{6}{|l|}{ Socio-economic variables } \\
\hline Share of new immigrants (\%) & 1.053 & 2.340 & -0.263 & -1.690 & -0.092 \\
\hline Share of boys (\%) & 49.135 & 9.307 & -0.048 & -0.435 & -0.024 \\
\hline Parent education level (index) ${ }^{2}$ & 2.565 & 0.115 & 0.391 & 9.103 & 0.498 \\
\hline \multicolumn{6}{|l|}{ School-type } \\
\hline For-profit & 0.375 & 0.484 & -0.012 & -0.480 & -0.026 \\
\hline Non-profit & 0.101 & 0.301 & 0.006 & 0.101 & 0.006 \\
\hline \multicolumn{6}{|l|}{ Municipality } \\
\hline Stockholm & 0.361 & 0.480 & 0.079 & 3.572 & 0.195 \\
\hline Gothenburg & 0.173 & 0.378 & 0.041 & 1.347 & 0.074 \\
\hline Malmö & 0.161 & 0.368 & 0.051 & 1.751 & 0.096 \\
\hline \multicolumn{6}{|l|}{ Competition } \\
\hline Density & 1.118 & 1.202 & 0.002 & 0.244 & 0.013 \\
\hline
\end{tabular}

1. Elasticity for expenditure per pupil. These estimates are from equations 8 in Table A.1.1 and 1 and 2 in Table A.1.2.

2. Education level is based on both parents highest educational attainment and runs from 1 to 3 . 
Annex Table 5. Model with one policy variable at a time (fixed effects)

Extension of Model [3] in Table 1.A.1

\begin{tabular}{|c|c|c|c|c|}
\hline Model type & $\mathrm{FE}[1]$ & $\mathrm{FE}[2]$ & $\mathrm{FE}[3]$ & $\mathrm{FE}[4]$ \\
\hline \multicolumn{5}{|l|}{ Policy variables } \\
\hline Spending per pupil & & $0.082^{*}$ & & \\
\hline Pupils per teacher & & & -0.002 & \\
\hline Share of certified teachers & & & & $0.092^{* * *}$ \\
\hline \multicolumn{5}{|l|}{ Year } \\
\hline 2014 & $-0.072^{* * *}$ & $-0.074^{* * *}$ & $-0.072^{* * *}$ & $-0.072^{* * *}$ \\
\hline 2015 & $-0.136^{* * *}$ & $-0.140^{* * *}$ & $-0.136^{\star * *}$ & $-0.132^{* * *}$ \\
\hline 2016 & -0.003 & -0.010 & -0.003 & -0.008 \\
\hline 2017 & $-0.126^{\star * *}$ & $-0.138^{* * *}$ & $-0.126^{* * *}$ & $-0.129^{\star \star *}$ \\
\hline \multicolumn{5}{|l|}{ Socio-economic variables } \\
\hline Share of new immigrants & $-0.238^{* * *}$ & $-0.241^{* * *}$ & $-0.238^{* * *}$ & $-0.236^{\star * *}$ \\
\hline Share of boys & $-0.049^{* *}$ & $-0.049^{* *}$ & $-0.049^{* *}$ & $-0.051^{* *}$ \\
\hline Parents' education & $0.337^{\star \star *}$ & $0.337^{\star * *}$ & $0.337^{* * *}$ & $0.339 * * *$ \\
\hline Constant & $1.762^{* \star *}$ & 0.829 & $1.784^{* * *}$ & $1.694^{* * *}$ \\
\hline \multicolumn{5}{|l|}{ Sample } \\
\hline Observations & 5720 & 5720 & 5720 & 5720 \\
\hline Schools & 1346 & 1346 & 1346 & 1346 \\
\hline \multicolumn{5}{|l|}{$\mathbf{R}^{2}$} \\
\hline Overall & 0.470 & 0.472 & 0.468 & 0.471 \\
\hline Within & 0.298 & 0.298 & 0.298 & 0.304 \\
\hline Between & 0.543 & 0.545 & 0.543 & 0.540 \\
\hline
\end{tabular}

$* * *, * *$ and $*$ indicate significance at respectively the $1 \%, 5 \%$ and $10 \%$ level. 
Annex Table 6. Model with one policy variable at a time (random effects)

Extension of Model [8] in Table 1.A.1

\begin{tabular}{|c|c|c|c|c|c|}
\hline Model type & $\mathrm{RE}[1]$ & $\mathrm{RE}[2]$ & $\mathrm{RE}[3]$ & $\mathrm{RE}[4]$ & $\mathrm{RE}[5]$ \\
\hline \multicolumn{6}{|l|}{ Policy variables } \\
\hline Spending per pupil & & $0.090^{* * *}$ & & & \\
\hline Pupils per teacher & & & -0.001 & & \\
\hline Share of certified teachers & & & & $0.086^{* * *}$ & \\
\hline Adaptation to student needs & & & & & $0.051^{* * *}$ \\
\hline \multicolumn{6}{|l|}{ School type } \\
\hline For-profit & $-0.023^{\star *}$ & $-0.024^{\star *}$ & $-0.023^{\star *}$ & $-0.015^{*}$ & $-0.035^{\star * *}$ \\
\hline Non-profit & 0.026 & 0.024 & 0.025 & $0.031^{*}$ & 0.002 \\
\hline \multicolumn{6}{|l|}{ Year } \\
\hline 2014 & $-0.069^{* * *}$ & $-0.072^{* * *}$ & $-0.069^{* * *}$ & $-0.069^{* * *}$ & $-0.069^{* * *}$ \\
\hline 2015 & $-0.129^{* * *}$ & $-0.134^{* * *}$ & $-0.129^{* * *}$ & $-0.125^{\star * *}$ & $-0.129^{* * *}$ \\
\hline 2016 & -0.003 & $-0.010^{*}$ & -0.002 & -0.007 & -0.002 \\
\hline 2017 & $-0.120^{\star * *}$ & $-0.133^{* * *}$ & $-0.120^{\star \star \star}$ & $-0.123^{* * *}$ & $-0.119^{* \star *}$ \\
\hline \multicolumn{6}{|l|}{ Socio-economic variables } \\
\hline Share of new immigrants & $-0.305^{\star * *}$ & $-0.310^{* * *}$ & $-0.307^{\star * *}$ & $-0.295^{\star * *}$ & $-0.312^{\star * *}$ \\
\hline Share of boys & $-0.055^{\star *}$ & $-0.056^{* *}$ & $-0.055^{\star *}$ & $-0.057^{\star *}$ & $-0.057^{\star *}$ \\
\hline Parents' education & $0.464^{* * *}$ & $0.466^{* * *}$ & $0.465^{* * *}$ & $0.455^{* * *}$ & $0.448^{* * *}$ \\
\hline \multicolumn{6}{|l|}{ Municipality } \\
\hline Stockholm & $0.041^{* * *}$ & $0.039^{* * *}$ & $0.042^{* * *}$ & $0.048^{* * *}$ & $0.045^{\star * *}$ \\
\hline Gothenburg & $0.024^{* * *}$ & $0.023^{* * *}$ & $0.024^{* * *}$ & $0.025^{\star * *}$ & $0.025^{* * *}$ \\
\hline Malmö & $0.028^{* * *}$ & $0.030^{* * *}$ & $0.029^{* * *}$ & $0.031^{* * *}$ & $0.031^{* * *}$ \\
\hline \multicolumn{6}{|l|}{ Competition } \\
\hline density & -0.002 & -0.006 & -0.002 & -0.003 & -0.001 \\
\hline Constant & $1.463^{* * *}$ & 0.438 & $1.468^{* * *}$ & $1.419^{* * *}$ & $1.148^{* * *}$ \\
\hline \multicolumn{6}{|l|}{ Sample } \\
\hline Observations & 4878 & 4878 & 4878 & 4878 & 4878 \\
\hline Schools & 1140 & 1140 & 1140 & 1140 & 1140 \\
\hline \multicolumn{6}{|l|}{$\mathbf{R}^{2}$} \\
\hline Overall & 0.501 & 0.502 & 0.501 & 0.504 & 0.517 \\
\hline Within & 0.279 & 0.279 & 0.279 & 0.286 & 0.280 \\
\hline Between & 0.575 & 0.577 & 0.576 & 0.577 & 0.595 \\
\hline
\end{tabular}

$* * *, * *$ and $*$ indicate significance at respectively the $1 \%, 5 \%$ and $10 \%$ level. 
Annex Table 7. Ordinary panel regressions with alternative survey measures

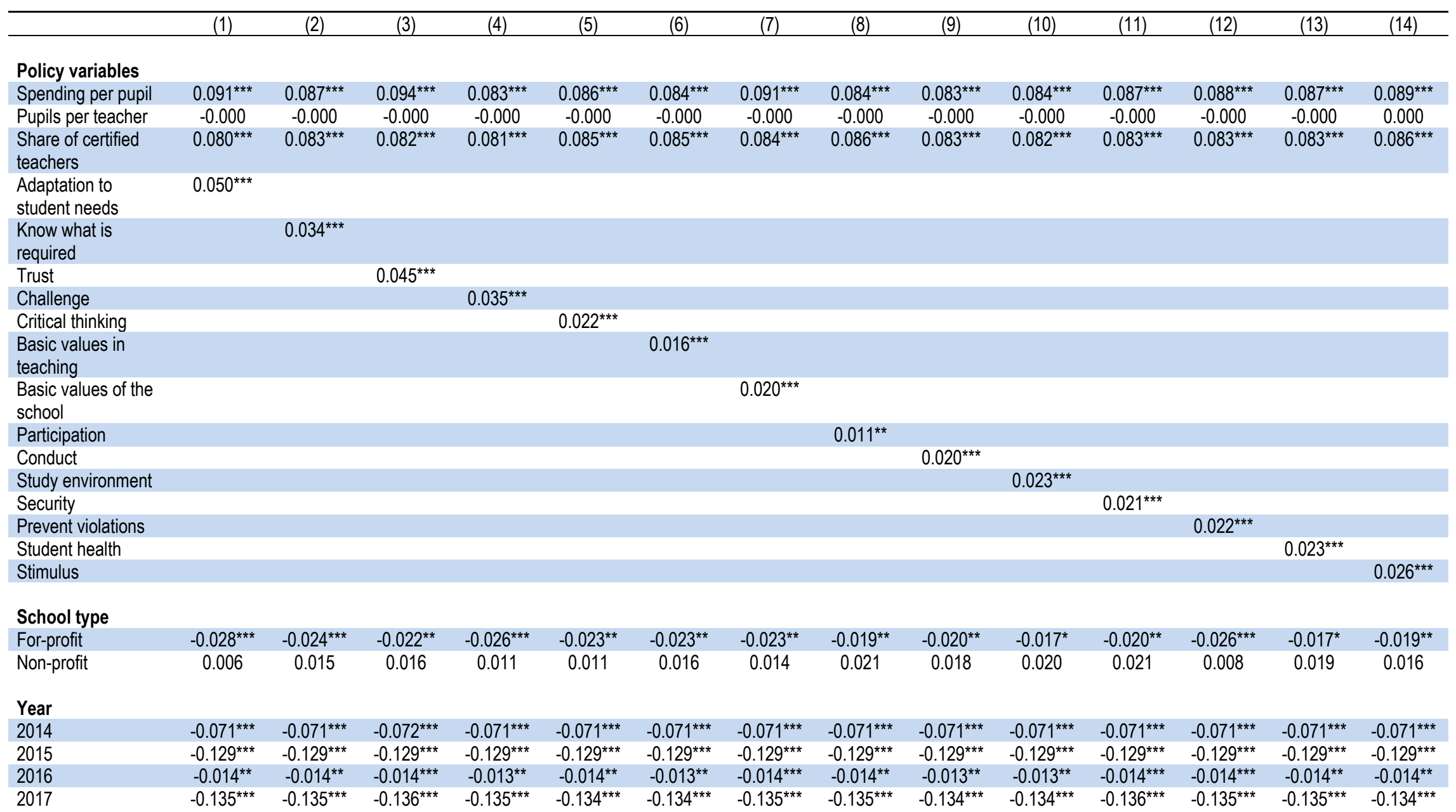




\section{Socio-economic}

\section{variables}

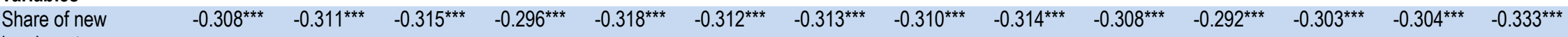

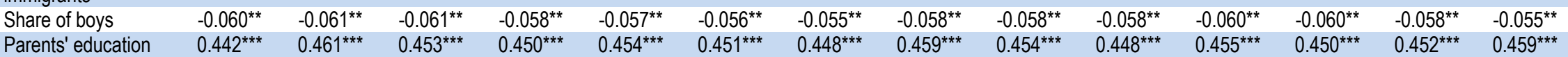

\section{Municipality}

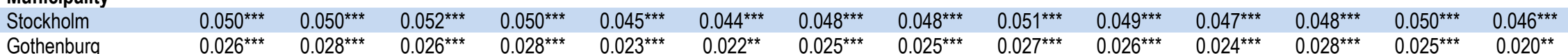

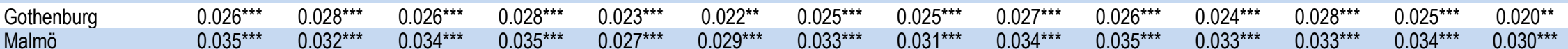

\section{Competition}

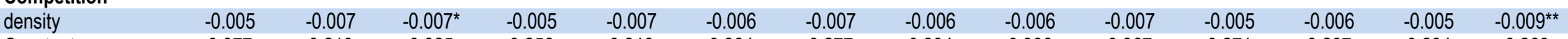

$\begin{array}{lrrrrrrrrrrrrrr}\text { Constant } & -0.005 & -0.007 & -0.007 & -0.005 & -0.007 & -0.006 & -0.007 & -0.006 & -0.006 & -0.007 & -0.005 & -0.006 & -0.005 & -0.009 \\ & 0.077 & 0.210 & 0.025 & 0.256 & 0.310 & 0.384 & 0.277 & 0.394 & 0.386 & 0.367 & 0.271 & 0.287 & 0.294 & 0.269\end{array}$

\begin{tabular}{lllllllllllllll} 
Sample & & & & & & & & & \\
Observations & 4878 & 4878 & 4878 & 4878 & 4878 & 4878 & 4878 & 4878 & 4878 & 4878 & 4878 & 4878 & 4878 & 4878 \\
Schools & 1140 & 1140 & 1140 & 1140 & 1140 & 1140 & 1140 & 1140 & 1140 & 1140 & 1140 & 1140 & 1140 & 1140 \\
& & & & & & & & & & & & & & \\
$\mathbf{R}^{2}$ & & & & & & & & & & & \\
Overall & 0.521 & 0.514 & 0.516 & 0.511 & 0.511 & 0.509 & 0.512 & 0.507 & 0.511 & 0.513 & 0.508 & 0.513 & 0.511 & 0.511 \\
Within & 0.287 & 0.286 & 0.287 & 0.287 & 0.287 & 0.287 & 0.287 & 0.286 & 0.287 & 0.287 & 0.287 & 0.287 & 0.287 & 0.286 \\
Between & 0.598 & 0.592 & 0.595 & 0.586 & 0.586 & 0.583 & 0.586 & 0.582 & 0.585 & 0.587 & 0.584 & 0.587 & 0.586 & 0.589 \\
\hline
\end{tabular}

$* * *, * *$ and * indicate significance at respectively the $1 \%, 5 \%$ and $10 \%$ level. Robust standard errors (clustered) are used. 


\section{Annex Table 8. Model with municipal fixed effects}

Extension of Model [8] in Table A.1.1.

\begin{tabular}{|c|c|c|c|c|c|}
\hline VARIABLES & $\begin{array}{c}(1) \\
\text { RE[1] } \\
\text { Whole sample }\end{array}$ & $\begin{array}{c}(2) \\
R E[2] \\
\text { Bottom quartile }\end{array}$ & $\begin{array}{c}(3) \\
\text { RE[3] } \\
\text { Top quartile }\end{array}$ & $\begin{array}{c}(4) \\
R E[4] \\
\text { Below median }\end{array}$ & $\begin{array}{c}(5) \\
R E[5] \\
\text { Above median }\end{array}$ \\
\hline \multicolumn{6}{|l|}{ Policy variables } \\
\hline Pupils per teacher & 0.001 & 0.001 & $0.002^{*}$ & -0.0002 & 0.002 \\
\hline $\begin{array}{l}\text { Share of certified } \\
\text { teachers }\end{array}$ & $0.083^{* * *}$ & $0.118^{* * *}$ & 0.022 & $0.078^{* * *}$ & $0.089^{* * *}$ \\
\hline $\begin{array}{l}\text { Adaptation to student } \\
\text { needs }\end{array}$ & $0.047^{* \star *}$ & $0.039^{* \star *}$ & $0.024^{* \star *}$ & $0.046^{* \star *}$ & $0.046^{* \star *}$ \\
\hline \multicolumn{6}{|l|}{ School type } \\
\hline For-profit & $-0.017^{*}$ & -0.033 & -0.009 & $-0.040^{*}$ & -0.013 \\
\hline Non-profit & 0.016 & $0.181^{*}$ & 0.025 & $0.085^{*}$ & 0.011 \\
\hline \multicolumn{6}{|l|}{ Year } \\
\hline 2014 & $-0.069^{* * *}$ & $-0.076^{\star * *}$ & $-0.074^{* * *}$ & $-0.070^{\star * *}$ & $-0.068^{* * *}$ \\
\hline 2015 & $-0.125^{* * *}$ & $-0.147^{* * *}$ & $-0.094^{* * *}$ & $-0.147^{* * *}$ & $-0.105^{\star * *}$ \\
\hline 2016 & -0.006 & 0.026 & $-0.036^{* * *}$ & 0.013 & $-0.025^{\star * *}$ \\
\hline 2017 & $-0.121^{* * *}$ & $-0.152^{\star \star *}$ & $-0.090^{\star * *}$ & $-0.144^{* * *}$ & $-0.103^{\star * *}$ \\
\hline \multicolumn{6}{|l|}{$\begin{array}{l}\text { Socio-economic } \\
\text { variables }\end{array}$} \\
\hline Share of new immigrants & $-0.318^{* * *}$ & $-0.412^{* * *}$ & $-0.227^{*}$ & $-0.320^{* * *}$ & $-0.215^{\star *}$ \\
\hline Share of boys & $-0.056^{\star *}$ & $-0.151^{* *}$ & $-0.069^{*}$ & -0.060 & -0.042 \\
\hline Parents' education & $0.430^{\star \star *}$ & $0.441^{* * *}$ & $0.396^{* \star *}$ & $0.432^{* \star *}$ & $0.429^{* \star *}$ \\
\hline \multicolumn{6}{|l|}{ Competition } \\
\hline density & $-0.011^{*}$ & -0.011 & -0.008 & -0.013 & -0.008 \\
\hline Constant & $1.151^{* * *}$ & $1.157^{\star \star \star}$ & $1.476^{\star \star \star}$ & $1.185^{\star \star \star}$ & $1.082^{\star \star *}$ \\
\hline \multicolumn{6}{|l|}{ Sample } \\
\hline Observations & 4878 & 1146 & 1302 & 2325 & 2553 \\
\hline Schools & 1,140 & 450 & 414 & 719 & 735 \\
\hline \multicolumn{6}{|l|}{$\mathbf{R}^{2}$} \\
\hline Overall & 0.583 & 0.477 & 0.516 & 0.445 & 0.543 \\
\hline Within & 0.287 & 0.316 & 0.246 & 0.297 & 0.290 \\
\hline Between & 0.696 & 0.515 & 0.609 & 0.524 & 0.598 \\
\hline
\end{tabular}

$* * *, * *$ and $*$ indicate significance at respectively the $1 \%, 5 \%$ and $10 \%$ level. 
Annex Table 9. Regression on Swedish test scores

\begin{tabular}{|c|c|c|c|c|}
\hline Model type & $\mathrm{RE}[1]$ & $\begin{array}{c}\text { RE IV [2] } \\
\text { Endogenous share of } \\
\text { certified teachers }\end{array}$ & $\begin{array}{c}\text { RE IV [3] } \\
\text { Endogenous spending } \\
\text { per pupil } \\
\end{array}$ & $\begin{array}{r}\text { SFA [4] } \\
\text { Exponential }\end{array}$ \\
\hline \multicolumn{5}{|l|}{ Policy variables } \\
\hline Spending per pupil & 0.007 & 0.009 & 0.048 & 0.037 \\
\hline Pupils per teacher & -0.000 & -0.000 & -0.000 & $-0.002^{*}$ \\
\hline $\begin{array}{l}\text { Share of certified } \\
\text { teachers }\end{array}$ & 0.003 & -0.129 & 0.005 & 0.002 \\
\hline $\begin{array}{l}\text { adaptation to student } \\
\text { needs }\end{array}$ & $0.028^{* * *}$ & $0.033^{* *}$ & $0.027^{\star \star \star}$ & $0.023^{\star \star *}$ \\
\hline \multicolumn{5}{|l|}{ School type } \\
\hline For-profit & -0.007 & -0.019 & -0.006 & 0.006 \\
\hline Non-profit & -0.024 & -0.033 & -0.024 & -0.008 \\
\hline \multicolumn{5}{|l|}{ Year } \\
\hline 2014 & -0.004 & -0.004 & -0.006 & -0.003 \\
\hline 2015 & $-0.036^{* * *}$ & $-0.043^{* *}$ & $-0.038^{* * *}$ & $-0.029^{* * *}$ \\
\hline 2016 & $0.013^{* * *}$ & 0.021 & 0.009 & $0.014^{* * *}$ \\
\hline \multicolumn{5}{|l|}{$\begin{array}{l}\text { Socio-economic } \\
\text { variables }\end{array}$} \\
\hline $\begin{array}{l}\text { Share of new } \\
\text { immigrants }\end{array}$ & 0.067 & 0.045 & 0.078 & 0.039 \\
\hline Share of boys & $-0.213^{* * *}$ & $-0.207^{* * *}$ & $-0.218^{* * *}$ & $-0.196^{\star * *}$ \\
\hline Parents' education & $0.313^{* * *}$ & $0.317^{* * *}$ & $0.317^{\star * *}$ & $0.260^{* * *}$ \\
\hline \multicolumn{5}{|l|}{ Municipality } \\
\hline Stockholm & $0.035^{\star * *}$ & $0.035^{* * *}$ & $0.034^{* * *}$ & $0.031^{* * *}$ \\
\hline Gothenburg & $0.013^{* *}$ & 0.016 & $0.013^{*}$ & $0.010^{*}$ \\
\hline Malmö & 0.011 & 0.013 & 0.012 & $0.013^{* *}$ \\
\hline \multicolumn{5}{|l|}{ Competition } \\
\hline Density & $0.012^{* * *}$ & $0.011^{* * *}$ & $0.010^{* *}$ & $0.011^{* * *}$ \\
\hline Constant & $1.710^{* \star *}$ & $1.732^{\star \star \star}$ & 1.229 & $1.589^{* * *}$ \\
\hline \multicolumn{5}{|l|}{ Sample } \\
\hline Observations & 3716 & 3716 & 3716 & 3716 \\
\hline Schools & 1079 & 1079 & 1079 & 1079 \\
\hline
\end{tabular}

$* * *, * *$ and $*$ indicate significance at respectively the $1 \%, 5 \%$ and $10 \%$ level. Robust standard errors (clustered) are used.

1. Uses the share of female teachers as an instrument for the share of certified teachers.

2. Uses the young age dependency ratio as an instrument for spending per pupil. 
Annex Table 10. Regression on English test scores

\begin{tabular}{|c|c|c|c|c|}
\hline Model type & $\mathrm{RE}$ [1] & $\begin{array}{c}\text { RE IV [2] } \\
\text { Endogenous share of } \\
\text { certified teachers' }\end{array}$ & $\begin{array}{c}\text { RE IV [3] } \\
\text { Endogenous spending } \\
\text { per pupil }^{2}\end{array}$ & $\begin{array}{c}\text { SFA [4] } \\
\text { Exponential }\end{array}$ \\
\hline \multicolumn{5}{|l|}{ Policy variables } \\
\hline Spending per pupil & $0.060^{\star * *}$ & 0.044 & 0.067 & $0.055^{\star \star \star}$ \\
\hline Pupils per teacher & $0.002^{* * *}$ & $0.002^{* *}$ & $0.002^{* * *}$ & $0.001^{* *}$ \\
\hline $\begin{array}{l}\text { Share of certified } \\
\text { teachers }\end{array}$ & 0.004 & 0.232 & 0.004 & 0.003 \\
\hline $\begin{array}{l}\text { adaptation to } \\
\text { student needs }\end{array}$ & $0.012^{\star * *}$ & 0.010 & $0.011^{* * *}$ & $0.012^{* * *}$ \\
\hline \multicolumn{5}{|l|}{ School type } \\
\hline For-profit & -0.003 & 0.031 & -0.004 & 0.005 \\
\hline Non-profit & 0.001 & 0.024 & -0.001 & 0.011 \\
\hline \multicolumn{5}{|l|}{ Year } \\
\hline 2014 & $-0.007^{\star *}$ & $-0.006^{* *}$ & $-0.007^{* *}$ & $-0.009^{\star * *}$ \\
\hline 2015 & $-0.024^{* * *}$ & -0.013 & $-0.024^{* * *}$ & $-0.022^{* * *}$ \\
\hline 2016 & $-0.016^{\star \star *}$ & -0.026 & $-0.017^{\star \star *}$ & $-0.013^{\star * *}$ \\
\hline \multicolumn{5}{|l|}{$\begin{array}{l}\text { Socio-economic } \\
\text { variables }\end{array}$} \\
\hline $\begin{array}{l}\text { Share of new } \\
\text { immigrants }\end{array}$ & $-0.446^{\star \star *}$ & $-0.414^{\star \star *}$ & $-0.454^{* * *}$ & $-0.328^{\star * *}$ \\
\hline Share of boys & -0.022 & -0.024 & $-0.023^{*}$ & $-0.027^{* *}$ \\
\hline Parents' education & $0.330^{* * *}$ & $0.311^{* * *}$ & $0.334^{* * *}$ & $0.290^{* * *}$ \\
\hline \multicolumn{5}{|l|}{ Municipality } \\
\hline Stockholm & $0.041^{* * *}$ & $0.059^{* *}$ & $0.041^{* * *}$ & $0.035^{\star * *}$ \\
\hline Gothenburg & $0.018^{* * *}$ & 0.013 & $0.017^{* \star *}$ & $0.013^{* * *}$ \\
\hline Malmö & $0.020^{* * *}$ & $0.028^{*}$ & $0.020^{* * *}$ & $0.017^{\star * *}$ \\
\hline \multicolumn{5}{|l|}{ Competition } \\
\hline Density & 0.000 & -0.002 & -0.000 & $0.003^{* *}$ \\
\hline Constant & $1.192^{* * *}$ & $1.271^{* * *}$ & $1.101^{*}$ & $1.391^{* * *}$ \\
\hline \multicolumn{5}{|l|}{ Sample } \\
\hline Observations & 3823 & 3823 & 3823 & 3823 \\
\hline Schools & 1097 & 1097 & 1097 & 1097 \\
\hline
\end{tabular}

$* * *, * *$ and $*$ indicate significance at respectively the $1 \%, 5 \%$ and $10 \%$ level. Robust standard errors (clustered) are used.

1. Uses the share of female teachers as an instrument for the share of certified teachers.

2. Uses the young age dependency ratio as an instrument for spending per pupil. 


\section{Annex Table 11. Robustness check for the competition indicator - share of pupils in private schools}

(whole sample)

\begin{tabular}{|c|c|c|c|c|}
\hline VARIABLES & $\mathrm{RE}$ [1] & $\begin{array}{c}\text { RE IV [2] } \\
\text { Endogenous share of } \\
\text { certified teachers' }\end{array}$ & $\begin{array}{c}\text { RE IV [3] } \\
\text { Endogenous } \\
\text { spending } \\
\text { per pupil } \\
\end{array}$ & $\begin{array}{c}\text { SFA [4] } \\
\text { Exponential }\end{array}$ \\
\hline \multicolumn{5}{|l|}{ Policy variables } \\
\hline Spending per pupil & $0.079^{* * *}$ & $0.084^{* \star *}$ & 0.001 & $0.063^{\star * *}$ \\
\hline Pupils per teacher & -0.000 & -0.000 & -0.001 & -0.001 \\
\hline Share of certified teachers & $0.078^{* * *}$ & -0.092 & $0.070^{\star * *}$ & $0.051^{* * *}$ \\
\hline Adaptation to student needs & $0.046^{* * *}$ & $0.050^{* * *}$ & $0.045^{* * *}$ & $0.039^{* * *}$ \\
\hline \multicolumn{5}{|l|}{ School type } \\
\hline For-profit & $-0.017^{\star}$ & $-0.035^{* *}$ & $-0.017^{*}$ & 0.008 \\
\hline Non-profit & 0.006 & -0.007 & 0.005 & $0.024^{*}$ \\
\hline \multicolumn{5}{|l|}{ Year } \\
\hline 2014 & $-0.075^{\star * *}$ & $-0.076^{\star \star *}$ & $-0.074^{\star * *}$ & $-0.073^{\star * *}$ \\
\hline 2015 & $-0.135^{\star \star \star}$ & $-0.144^{\star * *}$ & $-0.132^{\star \star *}$ & $-0.110^{\star \star *}$ \\
\hline 2016 & $-0.015^{* * *}$ & -0.007 & -0.009 & $-0.022^{* * *}$ \\
\hline 2017 & $-0.141^{\star \star *}$ & $-0.136^{\star \star *}$ & $-0.131^{\star * *}$ & $-0.118^{\star \star \star}$ \\
\hline \multicolumn{5}{|l|}{ Socio-economic variables } \\
\hline Share of new immigrants & $-0.266^{\star * *}$ & $-0.287^{\star \star *}$ & $-0.258^{\star * *}$ & $-0.227^{\star * *}$ \\
\hline Share of boys & $-0.052^{* *}$ & $-0.048^{* *}$ & $-0.051^{* *}$ & $-0.037^{\star}$ \\
\hline Parents' education & $0.451^{* \star *}$ & $0.476^{* * *}$ & $0.475^{* * *}$ & $0.377^{\star * *}$ \\
\hline \multicolumn{5}{|l|}{ Municipality } \\
\hline Stockholm & $0.046^{* * *}$ & $0.033^{\star \star *}$ & $0.049^{* * *}$ & $0.051^{* * *}$ \\
\hline Gothenburg & $0.024^{\star * *}$ & $0.023^{\star \star \star}$ & $0.024^{* * *}$ & $0.027^{\star \star *}$ \\
\hline Malmö & $0.026^{* * *}$ & $0.022^{* *}$ & $0.024^{* * *}$ & $0.037^{* * *}$ \\
\hline \multicolumn{5}{|l|}{ Competition } \\
\hline Share of pupils attending private schools & $-0.047^{* * *}$ & $-0.044^{* * *}$ & $-0.055^{\star \star \star}$ & $-0.039^{\star \star *}$ \\
\hline Constant & 0.228 & 0.213 & $1.085^{*}$ & $0.727^{\star \star \star}$ \\
\hline \multicolumn{5}{|l|}{ Sample } \\
\hline Observations & 5668 & 5668 & 5668 & 5668 \\
\hline Schools & 1335 & 1335 & 1335 & 1335 \\
\hline \multicolumn{5}{|l|}{$\mathbf{R}^{2}$} \\
\hline Overall & 0.514 & 0.492 & 0.514 & - \\
\hline Within & 0.299 & 0.275 & 0.296 & - \\
\hline Between & 0.586 & 0.565 & 0.587 & - \\
\hline
\end{tabular}

$* * *, * *$ and $*$ indicate significance at respectively the $1 \%, 5 \%$ and $10 \%$ level. Robust standard errors (clustered) are used.

1. Uses the share of female teachers as an instrument for the share of certified teachers.

2. Uses the young age dependency ratio as an instrument for spending per pupil. 


\section{Annex Table 12. Robustness check for the competition indicator - share of pupils in private} schools

(sub-samples)

\begin{tabular}{|c|c|c|c|c|c|c|c|c|}
\hline Model type & $\begin{array}{c}\text { RE[1] } \\
\text { Bottom } \\
\text { quartile } \\
\text { soc } \text { stat }^{1}\end{array}$ & $\begin{array}{c}\text { RE[2] } \\
\text { Top quartile } \\
\text { soc_stat }{ }^{1}\end{array}$ & $\begin{array}{c}\text { RE[3] } \\
\text { Below } \\
\text { median } \\
\text { soc } \text { stat }^{1}\end{array}$ & $\begin{array}{c}\text { RE[4] } \\
\text { Above } \\
\text { median } \\
\text { soc } \text { stat }^{1}\end{array}$ & $\begin{array}{c}\text { RE[5] } \\
\text { Bottom } \\
\text { quartile } \\
\text { soc } \text { stat }^{2}\end{array}$ & $\begin{array}{c}\mathrm{RE}[6] \\
\text { Top quartile } \\
\text { soc_stat }^{2}\end{array}$ & $\begin{array}{c}\text { RE[7] } \\
\text { Below } \\
\text { median } \\
\text { soc } \text { stat }^{2}\end{array}$ & $\begin{array}{c}\text { RE[8] } \\
\text { Above } \\
\text { median } \\
\text { soc } \text { stat }^{2}\end{array}$ \\
\hline
\end{tabular}

\section{Policy variables}

\begin{tabular}{|c|c|c|c|c|c|c|c|c|}
\hline Spending per pupil & $0.164^{* * *}$ & 0.057 & $0.075^{*}$ & $0.057^{*}$ & 0.100 & 0.035 & $0.110^{\star *}$ & 0.033 \\
\hline Pupils per teacher & 0.000 & $0.002^{*}$ & -0.001 & 0.001 & -0.000 & 0.002 & -0.000 & -0.001 \\
\hline Share of certified teachers & $0.112^{* * *}$ & 0.013 & $0.076^{* * *}$ & $0.076^{* * *}$ & $0.122^{* * *}$ & 0.015 & $0.083^{* \star *}$ & $0.073^{* * *}$ \\
\hline Adaptation to student needs & $0.048^{\star * *}$ & $0.034^{* * *}$ & $0.045^{\star \star *}$ & $0.050^{\star * *}$ & $0.068^{\star * *}$ & $0.034^{* * *}$ & $0.046^{* * *}$ & $0.047^{* * *}$ \\
\hline \multicolumn{9}{|l|}{ School type } \\
\hline For-profit & -0.028 & -0.012 & $-0.045^{\star * *}$ & $-0.015^{*}$ & -0.008 & -0.005 & $-0.032^{*}$ & $-0.018^{* *}$ \\
\hline Non-profit & $0.202^{* * *}$ & 0.003 & 0.051 & -0.009 & $0.300^{* * *}$ & -0.003 & $0.118^{* *}$ & -0.015 \\
\hline
\end{tabular}

\begin{tabular}{|c|c|c|c|c|c|c|c|c|}
\hline \\
\hline 2014 & $-0.080^{* * *}$ & $-0.074^{* * *}$ & $-0.078^{* * *}$ & $-0.071^{* * *}$ & $-0.085^{\star * *}$ & $-0.071^{* * *}$ & $-0.081^{* * *}$ & $-0.068^{* * *}$ \\
\hline 2015 & $-0.152^{\star * \star}$ & $-0.101^{* * *}$ & $-0.151^{* * *}$ & $-0.115^{\star \star *}$ & $-0.168^{* * *}$ & $-0.103^{\star \star *}$ & $-0.154^{* * *}$ & $-0.114^{* * *}$ \\
\hline 2016 & 0.0121 & $-0.042^{\star * *}$ & 0.005 & $-0.032^{\star * *}$ & 0.011 & $-0.039^{\star * *}$ & 0.000 & $-0.029^{* * *}$ \\
\hline 2017 & $-0.175^{\star \star *}$ & $-0.103^{\star * *}$ & $-0.158^{\star * *}$ & $-0.117^{\text {***}}$ & $-0.167^{\text {***}}$ & $-0.099^{\star \star *}$ & $-0.164^{* * *}$ & $-0.115^{\star \star \star}$ \\
\hline
\end{tabular}

\section{Socio-economic variables}

\begin{tabular}{|c|c|c|c|c|c|c|c|c|}
\hline Share of new immigrants & $-0.359^{* * *}$ & $-0.257^{* *}$ & $-0.262^{* * *}$ & $-0.210^{\star * *}$ & $-0.300^{* * *}$ & $-0.266^{* * *}$ & $-0.260^{* * *}$ & $-0.194^{* * *}$ \\
\hline Share of boys & $-0.131^{* *}$ & -0.030 & -0.054 & -0.033 & $-0.096^{*}$ & -0.028 & $-0.059^{*}$ & $-0.037^{\star}$ \\
\hline Parents' education & $0.480^{* * *}$ & $0.405^{\star * *}$ & $0.438^{* * \star}$ & $0.445^{\star \star \star}$ & $0.404^{\star * \star}$ & $0.433^{\star \star \star}$ & $0.409^{\star \star \star}$ & $0.442^{* \star *}$ \\
\hline
\end{tabular}

\begin{tabular}{|c|c|c|c|c|c|c|c|c|}
\hline unicipality & & & & & & & & \\
\hline Stockholm & -0.003 & $0.082^{* \star *}$ & $0.019^{*}$ & $0.072^{* * *}$ & 0.005 & $0.076^{* \star *}$ & 0.012 & $0.080^{* * *}$ \\
\hline Gothenburg & 0.019 & $0.041^{* * *}$ & $0.034^{* *}$ & $0.032^{* * *}$ & 0.016 & $0.041^{* * *}$ & 0.025 & $0.035^{\star \star *}$ \\
\hline Malmö & -0.012 & $0.048^{* * *}$ & 0.010 & $0.054^{* * *}$ & -0.017 & $0.039^{* * *}$ & 0.000 & $0.055^{\star \star *}$ \\
\hline
\end{tabular}

\section{Competition}

\begin{tabular}{lcccccccc}
$\begin{array}{l}\text { Share of pupils attending } \\
\text { private schools }\end{array}$ & $-0.119^{* * *}$ & -0.004 & $-0.075^{* * *}$ & -0.021 & $-0.141^{* * *}$ & -0.001 & $-0.079^{* * *}$ & -0.019 \\
$\begin{array}{l}\text { Constant } \\
\text { Sample }\end{array}$ & -0.750 & 0.659 & 0.336 & 0.423 & -0.032 & $0.843^{* *}$ & -0.027 & $0.749^{*}$ \\
Observations & 1432 & 1376 & 2875 & 2793 & 1429 & 1377 & 2880 & 2788 \\
\hline
\end{tabular}

Schools

\begin{tabular}{|c|c|c|c|c|c|c|c|c|}
\hline \multicolumn{9}{|l|}{$\mathbf{R}^{2}$} \\
\hline Overall & 0.327 & 0.417 & 0.321 & 0.466 & 0.360 & 0.432 & 0.335 & 0.469 \\
\hline Within & 0.319 & 0.257 & 0.305 & 0.297 & 0.317 & 0.300 & 0.314 & 0.316 \\
\hline Between & 0.259 & 0.427 & 0.313 & 0.462 & 0.386 & 0.486 & 0.350 & 0.500 \\
\hline
\end{tabular}

$* * * * *$ and $*$ indicate significance at respectively the $1 \%, 5 \%$ and $10 \%$ level. Robust standard errors (clustered) are used.

1. Quartiles and median are calculated after sorting schools according to socio-economic chararcteristics of their students.

2. Quartiles and median are calculated after sorting schools according to their average socio-economic characteristics index over 2013-2017. 


\section{Annex Table 13. Robustness check for the competition indicator - share of pupils in private} schools

(impact of changes in exogenous variables)

\begin{tabular}{|c|c|c|c|c|c|}
\hline & \multirow{2}{*}{ Mean } & \multirow{2}{*}{$\begin{array}{c}\text { Standard } \\
\text { deviation }(\mathrm{sd})\end{array}$} & \multirow{2}{*}{$\begin{array}{l}\text { Semi- } \\
\text { elasticity }{ }^{1}\end{array}$} & \multicolumn{2}{|c|}{$\begin{array}{l}\text { Impact of one full sample } \\
\text { sd change }\end{array}$} \\
\hline & & & & $\%$ of test score & $\begin{array}{l}\text { In sd of test } \\
\text { scores }\end{array}$ \\
\hline \multicolumn{6}{|l|}{ Whole sample } \\
\hline Mathematics test score & 11.445 & 2.095 & .. & & \\
\hline \multicolumn{6}{|l|}{ Policy variables } \\
\hline Spending per pupil (SEK) & 96821 & 10389 & 0.079 & 0.848 & 0.046 \\
\hline Pupils per teacher & 12.424 & 2.428 & 0.000 & -0.099 & -0.005 \\
\hline Share of certified teachers (\%) & 72.151 & 20.442 & 0.078 & 1.595 & 0.087 \\
\hline Adaptation to student needs & 6.914 & 0.546 & 0.046 & 2.521 & 0.138 \\
\hline \multicolumn{6}{|l|}{ Socio-economic variables } \\
\hline Share of new immigrants (\%) & 4.581 & 6.480 & -0.266 & -1.721 & -0.094 \\
\hline Share of boys (\%) & 51.803 & 8.874 & -0.052 & -0.458 & -0.025 \\
\hline Parent education level (index) ${ }^{2}$ & 2.262 & 0.228 & 0.451 & 10.271 & 0.561 \\
\hline \multicolumn{6}{|l|}{ School-type } \\
\hline For-profit & 0.174 & 0.379 & -0.017 & -0.660 & -0.036 \\
\hline Non-profit & 0.031 & 0.173 & 0.006 & 0.108 & 0.006 \\
\hline \multicolumn{6}{|l|}{ Municipality } \\
\hline Stockholm & 0.259 & 0.438 & 0.046 & 1.997 & 0.109 \\
\hline Gothenburg & 0.120 & 0.325 & 0.024 & 0.788 & 0.043 \\
\hline Malmö & 0.129 & 0.335 & 0.026 & 0.856 & 0.047 \\
\hline \multicolumn{6}{|l|}{ Competition } \\
\hline Share of pupils attending private school & 0.215 & 0.199 & -0.047 & -0.931 & -0.051 \\
\hline \multicolumn{6}{|l|}{ Bottom quartile } \\
\hline Mathematics test score & 9.897 & 1.880 & .. & & \\
\hline \multicolumn{6}{|l|}{ Policy variables } \\
\hline Spending per pupil (SEK) & 98782 & 10712 & 0.164 & 1.720 & 0.094 \\
\hline Pupils per teacher & 11.429 & 2.289 & 0.000 & 0.019 & 0.001 \\
\hline Share of certified teachers (\%) & 69.904 & 20.088 & 0.112 & 2.291 & 0.125 \\
\hline Adaptation to student needs & 6.777 & 0.519 & 0.048 & 2.600 & 0.142 \\
\hline \multicolumn{6}{|l|}{ Socio-economic variables } \\
\hline Share of new immigrants (\%) & 11.226 & 8.309 & -0.359 & -2.325 & -0.127 \\
\hline Share of boys (\%) & 53.633 & 8.537 & -0.131 & -1.160 & -0.063 \\
\hline Parent education level (index) ${ }^{2}$ & 2.004 & 0.137 & 0.480 & 10.935 & 0.597 \\
\hline
\end{tabular}


School-type

$\begin{array}{lccccc}\text { For-profit } & 0.045 & 0.207 & -0.028 & -1.073 & -0.059 \\ \text { Non-profit } & 0.005 & 0.070 & 0.202 & 3.493 & 0.191\end{array}$

Municipality

$\begin{array}{llllll}\text { Stockholm } & 0.248 & 0.432 & -0.003 & -0.150 & -0.008 \\ \text { Gothenburg } & 0.071 & 0.256 & 0.019 & 0.630 & 0.034 \\ \text { Malmö } & 0.124 & 0.329 & -0.012 & -0.389 & -0.021\end{array}$

Competition

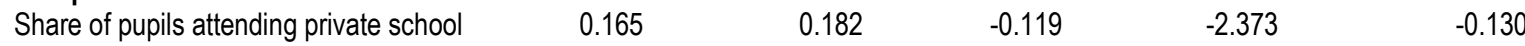

\begin{tabular}{llll}
\hline Top quartile & & & \\
\hline Mathematics test score & 13.412 & 1.580 & ..
\end{tabular}

Policy variables

$\begin{array}{lcccccc}\text { Spending per pupil (SEK) } & 97451 & 10846 & 0.057 & 0.604 & 0.033 \\ \text { Pupils per teacher } & 13.556 & 2.316 & 0.002 & 0.556 & 0.030 \\ \text { Share of certified teachers (\%) } & 75.540 & 20.652 & 0.013 & 0.257 & 0.014 \\ \text { Adaptation to student needs } & 7.143 & 0.564 & 0.034 & 1.851 & 0.101\end{array}$

Socio-economic variables

Share of new immigrants $(\%)$

Share of boys (\%)

Parent education level (index) $)^{2}$

$\begin{array}{ccc}1.074 & 2.324 & -0.25 \\ 49.166 & 9.330 & -0.03 \\ 2.563 & 0.114 & 0.40\end{array}$

-0.2
-0.030

$-0.257 \quad-1.668$

$-0.091$

$-0.030 \quad-0.264$

$-0.014$

School-type

$\begin{array}{ll}\text { For-profit } & 0.35 \\ \text { Non-profit } & 0.096 \\ \text { Municipality } & \end{array}$

$\begin{array}{lllllll}\text { Stockholm } & 0.360 & 0.480 & 0.082 & 3.589 & 0.196 \\ \text { Gothenburg } & 0.166 & 0.373 & 0.041 & 1.343 & 0.073 & 0.088 \\ \text { Malmö } & 0.163 & 0.369 & 0.048 & 1.616 & & \\ & & & & & -0.004\end{array}$

1. Elasticity for expenditure per pupil. These estimates are from equations 1 in Table A.1.9 and 1 and 2 in Table A.1.10.

2. Education level is based on both parents highest educational attainment and runs from 1 to 3 . 
Annex Table 14. Robustness check for the competition indicator - distance between schools

(whole sample)

\begin{tabular}{|c|c|c|c|c|}
\hline VARIABLES & $\begin{array}{c}(1) \\
R E[1]\end{array}$ & $\begin{array}{c}(2) \\
\text { RE [2] } \\
\text { Endogenous share of } \\
\text { certified teachers' } \\
\end{array}$ & $\begin{array}{c}(3) \\
\text { RE [3] } \\
\text { Endogenous } \\
\text { spending per pupil } \\
\end{array}$ & $\begin{array}{c}(4) \\
\text { SFA [4] } \\
\text { Exponential }\end{array}$ \\
\hline \multicolumn{5}{|l|}{ Policy variables } \\
\hline Spending per pupil & $0.077^{\star * *}$ & $0.088^{\star * \star}$ & -0.008 & $0.059^{* * *}$ \\
\hline Pupils per teacher & -0.000 & -0.000 & -0.001 & -0.001 \\
\hline Share of certified teachers & $0.079^{* * *}$ & -0.124 & $0.063^{* * *}$ & $0.045^{\star * *}$ \\
\hline Adaptation to student needs & $0.050^{* * *}$ & $0.054^{* \star *}$ & $0.048^{* * *}$ & $0.040^{\star \star \star}$ \\
\hline \multicolumn{5}{|l|}{ School type } \\
\hline For-profit & $-0.027^{\star * *}$ & $-0.048^{* * *}$ & $-0.027^{\star * *}$ & 0.001 \\
\hline Non-profit & 0.005 & -0.009 & 0.003 & $0.024^{*}$ \\
\hline \multicolumn{5}{|l|}{ Year } \\
\hline 2014 & $-0.071^{* * *}$ & $-0.071^{* * *}$ & $-0.070^{\star * *}$ & $-0.070^{\star * *}$ \\
\hline 2015 & $-0.129^{* * *}$ & $-0.139^{* * *}$ & $-0.125^{\star * *}$ & $-0.104^{\star * *}$ \\
\hline 2016 & $-0.012^{* *}$ & -0.004 & -0.005 & $-0.019^{* * *}$ \\
\hline 2017 & $-0.133^{* * *}$ & $-0.127^{* * *}$ & $-0.121^{* * *}$ & $-0.111^{* * *}$ \\
\hline \multicolumn{5}{|l|}{ Socio-economic variables } \\
\hline Share of new immigrants & $-0.310^{* * *}$ & $-0.338^{* * *}$ & $-0.308^{* * *}$ & $-0.247^{* * *}$ \\
\hline Share of boys & $-0.060^{\star *}$ & $-0.057^{\star \star}$ & $-0.062^{* \star}$ & $-0.049^{* *}$ \\
\hline Parents' education & $0.441^{* * *}$ & $0.468^{* \star *}$ & $0.469^{* * *}$ & $0.372^{* * *}$ \\
\hline \multicolumn{5}{|l|}{ Municipality } \\
\hline Stockholm & $0.047^{* * *}$ & $0.032^{* * *}$ & $0.050^{* * *}$ & $0.047^{* * *}$ \\
\hline Gothenburg & $0.025^{\star \star *}$ & $0.022^{* *}$ & $0.024^{* * *}$ & $0.027^{\star \star \star}$ \\
\hline Malmö & $0.033^{* * *}$ & $0.029^{* * *}$ & $0.032^{* * *}$ & $0.039^{* * *}$ \\
\hline \multicolumn{5}{|l|}{ Competition } \\
\hline Distance between schools & -0.005 & $-0.007^{* *}$ & $-0.005^{\star}$ & -0.004 \\
\hline Constant & 0.246 & 0.178 & $1.179^{*}$ & $0.783^{* * *}$ \\
\hline \multicolumn{5}{|l|}{ Sample } \\
\hline Observations & 4878 & 4878 & 4878 & 4878 \\
\hline Schools & 1140 & 1140 & 1140 & 1140 \\
\hline \multicolumn{5}{|l|}{$\mathbf{R}^{2}$} \\
\hline Overall & 0.521 & 0.491 & 0.521 & \\
\hline Within & 0.287 & 0.255 & 0.284 & . \\
\hline Between & 0.599 & 0.570 & 0.599 & 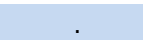 \\
\hline
\end{tabular}

$* * *, * *$ and $*$ indicate significance at respectively the $1 \%, 5 \%$ and $10 \%$ level. Robust standard errors (clustered) are used.

1. Uses the share of female teachers as an instrument for the share of certified teachers.

2. Uses the young age dependency ratio as an instrument for spending per pupil. 


\section{Annex Table 15. Robustness check for the competition indicator - distance between schools}

(sub-samples)

\begin{tabular}{|c|c|c|c|c|c|c|c|c|}
\hline VARIABLES & $\begin{array}{c}\text { RE[1] } \\
\text { Bottom } \\
\text { quartile } \\
\text { soc_stat }{ }^{1}\end{array}$ & $\begin{array}{c}\mathrm{RE}[2] \\
\text { Top quartile } \\
\text { soc_stat }{ }^{1}\end{array}$ & $\begin{array}{c}\text { RE[3] } \\
\text { Below } \\
\text { median } \\
\text { soc_stat }{ }^{1}\end{array}$ & $\begin{array}{c}\text { RE[4] } \\
\text { Above } \\
\text { median } \\
\text { soc_stat }{ }^{1} \\
\end{array}$ & $\begin{array}{c}\text { RE[5] } \\
\text { Bottom } \\
\text { quartile } \\
\text { soc_stat }{ }^{2} \\
\end{array}$ & $\begin{array}{c}\text { RE[6] } \\
\text { Top quartile } \\
\text { soc_stat }{ }^{2}\end{array}$ & $\begin{array}{c}\text { RE[7] } \\
\text { Below } \\
\text { median } \\
\text { soc_stat }{ }^{2} \\
\end{array}$ & $\begin{array}{c}\text { RE[8] } \\
\text { Above } \\
\text { median } \\
\text { soc_stat }{ }^{2}\end{array}$ \\
\hline \multicolumn{9}{|l|}{ Policy variables } \\
\hline Spending per pupil & $0.138^{*}$ & 0.058 & 0.068 & $0.060^{*}$ & 0.089 & 0.039 & $0.108^{* *}$ & 0.038 \\
\hline Pupils per teacher & -0.000 & $0.002^{*}$ & -0.002 & 0.001 & -0.001 & 0.002 & -0.001 & -0.000 \\
\hline Share of certified teachers & $0.108^{* * *}$ & 0.021 & $0.076^{* * *}$ & $0.079^{* * *}$ & $0.128^{* * *}$ & 0.007 & $0.082^{* * *}$ & $0.075^{\star * *}$ \\
\hline Adaptation to student needs & $0.056^{\star * *}$ & $0.035^{* * *}$ & $0.051^{* * \star}$ & $0.052^{* * *}$ & $0.078^{\star * *}$ & $0.032^{* * *}$ & $0.055 t^{\star * *}$ & $0.046^{\star * *}$ \\
\hline \multicolumn{9}{|l|}{ School type } \\
\hline For-profit & $-0.052^{*}$ & -0.012 & $-0.055^{\star * *}$ & $-0.020^{* *}$ & -0.036 & -0.006 & $-0.046^{* *}$ & $-0.022^{* *}$ \\
\hline Non-profit & $0.178^{* *}$ & 0.007 & $0.081^{*}$ & -0.009 & $0.271^{\star \star *}$ & 0.009 & $0.095^{*}$ & -0.008 \\
\hline \multicolumn{9}{|l|}{ Year } \\
\hline 2014 & $-0.078^{* * *}$ & $-0.074^{* * *}$ & $-0.071^{* * *}$ & $-0.070^{* * *}$ & $-0.081^{* * *}$ & $-0.069^{* * *}$ & $-0.075^{* * *}$ & $-0.066^{* * *}$ \\
\hline 2015 & $-0.153^{* * *}$ & $-0.098^{\star * *}$ & $-0.147^{* * *}$ & $-0.110^{* \star *}$ & $-0.161^{* * *}$ & $-0.097^{\star * *}$ & $-0.148^{\star * *}$ & $-0.110^{* * *}$ \\
\hline 2016 & 0.016 & $-0.042^{* * *}$ & 0.010 & $-0.031^{* * *}$ & 0.015 & $-0.035^{\star * *}$ & 0.006 & $-0.027^{* * *}$ \\
\hline 2017 & $-0.172^{\star * *}$ & $-0.099^{\star \star *}$ & $-0.151^{\star \star \star}$ & $-0.113^{\star \star \star}$ & $-0.160^{* \star \star}$ & $-0.090^{\star \star *}$ & $-0.156^{\star * *}$ & $-0.110^{* * *}$ \\
\hline \multicolumn{9}{|l|}{ Socio-economic variables } \\
\hline Share of new immigrants & $-0.422^{* * *}$ & $-0.254^{* *}$ & $-0.317^{\star \star *}$ & $-0.211^{* * *}$ & $-0.378^{\star * *}$ & $-0.301^{* * *}$ & $-0.317^{\star \star *}$ & $-0.213^{\star \star *}$ \\
\hline Share of boys & $-0.144^{* *}$ & $-0.050^{*}$ & $-0.077^{\star *}$ & $-0.042^{*}$ & $-0.107^{\star}$ & -0.039 & $-0.079^{* *}$ & $-0.038^{*}$ \\
\hline Parents' education & $0.479^{* \star *}$ & $0.392^{* * *}$ & $0.445^{\star * *}$ & $0.438^{* * *}$ & $0.405^{\star * *}$ & $0.388^{* * *}$ & $0.413^{* * *}$ & $0.424^{* * *}$ \\
\hline \multicolumn{9}{|l|}{ Municipality } \\
\hline Stockholm & 0.001 & $0.081^{* \star *}$ & $0.021^{*}$ & $0.071^{* * *}$ & 0.015 & $0.077^{\star \star *}$ & 0.015 & $0.080^{* * *}$ \\
\hline Gothenburg & 0.005 & $0.041^{* * *}$ & $0.030^{*}$ & $0.032^{\star * *}$ & 0.007 & $0.042^{\star * *}$ & 0.016 & $0.039^{\star * *}$ \\
\hline Malmö & 0.007 & $0.053^{\star * *}$ & 0.022 & $0.053^{* * *}$ & 0.002 & $0.051^{\star \star *}$ & 0.007 & $0.062^{\star * *}$ \\
\hline \multicolumn{9}{|l|}{ Competition } \\
\hline Distance & $-0.028^{* *}$ & -0.002 & $-0.018^{* *}$ & -0.002 & $-0.049^{* * *}$ & -0.001 & $-0.023^{\star *}$ & -0.002 \\
\hline Constant & -0.506 & 0.674 & 0.366 & 0.381 & 0.015 & $0.932^{* *}$ & -0.048 & $0.719^{*}$ \\
\hline \multicolumn{9}{|l|}{ Sample } \\
\hline Observations & 1146 & 1302 & 2325 & 2553 & 1140 & 1301 & 2310 & 2568 \\
\hline Schools & 450 & 414 & 719 & 735 & 281 & 292 & 552 & 588 \\
\hline \multicolumn{9}{|l|}{$\mathbf{R}^{2}$} \\
\hline Overall & 0.328 & 0.416 & 0.327 & 0.465 & 0.364 & 0.434 & 0.339 & 0.470 \\
\hline Within & 0.314 & 0.247 & 0.297 & 0.290 & 0.303 & 0.277 & 0.305 & 0.302 \\
\hline Between & 0.262 & 0.429 & 0.331 & 0.468 & 0.395 & 0.497 & 0.362 & 0.502 \\
\hline
\end{tabular}

$* * *, * *$ and $*$ indicate significance at respectively the $1 \%, 5 \%$ and $10 \%$ level. Robust standard errors (clustered) are used.

1. Quartiles and median are calculated after sorting schools according to socio-economic chararcteristics of their students.

2. Quartiles and median are calculated after sorting schools according to their average socio-economic characteristics index over 2013-2017. 
Annex Table 16. Robustness check for the competition indicator - distance between schools

(impact of changes in exogenous variables)

\begin{tabular}{|c|c|c|c|c|c|}
\hline & \multirow{2}{*}{ Mean } & \multirow{2}{*}{$\begin{array}{l}\text { Standard } \\
\text { deviation } \\
\text { (sd) }\end{array}$} & \multirow{2}{*}{$\begin{array}{l}\text { Semi- } \\
\text { elasticity }{ }^{1}\end{array}$} & \multicolumn{2}{|c|}{$\begin{array}{l}\text { Impact of one full sample } \\
\text { sd change }\end{array}$} \\
\hline & & & & $\%$ of test score & $\begin{array}{l}\text { In sd of test } \\
\text { scores }\end{array}$ \\
\hline \multicolumn{6}{|l|}{ Whole sample } \\
\hline Mathematics test score & 11.546 & 2.112 & & & \\
\hline \multicolumn{6}{|l|}{ Policy variables } \\
\hline Spending per pupil (SEK) & 96555 & 10220 & 0.077 & 0.813 & 0.044 \\
\hline Pupils per teacher & 12.610 & 2.411 & 0.000 & -0.072 & -0.004 \\
\hline Share of certified teachers (\%) & 72.113 & 20.453 & 0.079 & 1.606 & 0.088 \\
\hline Adaptation to student needs & 6.933 & 0.556 & 0.050 & 2.750 & 0.150 \\
\hline \multicolumn{6}{|l|}{ Socio-economic variables } \\
\hline Share of new immigrants (\%) & 4.383 & 6.424 & -0.310 & -1.991 & -0.109 \\
\hline Share of boys (\%) & 51.836 & 8.992 & -0.060 & -0.539 & -0.029 \\
\hline Parent education level (index) ${ }^{2}$ & 2.275 & 0.233 & 0.441 & 10.267 & 0.561 \\
\hline \multicolumn{6}{|l|}{ School-type } \\
\hline For-profit & 0.199 & 0.400 & -0.027 & -1.083 & -0.059 \\
\hline Non-profit & 0.035 & 0.183 & 0.005 & 0.094 & 0.005 \\
\hline \multicolumn{6}{|l|}{ Municipality } \\
\hline Stockholm & 0.286 & 0.452 & 0.047 & 2.116 & 0.116 \\
\hline Gothenburg & 0.127 & 0.333 & 0.025 & 0.832 & 0.045 \\
\hline Malmö & 0.137 & 0.344 & 0.033 & 1.139 & 0.062 \\
\hline \multicolumn{6}{|l|}{ Competition of schools } \\
\hline Distance & 0.303 & 1.000 & -0.005 & -0.491 & -0.027 \\
\hline \multicolumn{6}{|l|}{ Bottom quartile } \\
\hline Mathematics test score & 9.872 & 1.914 & .. & & \\
\hline \multicolumn{6}{|l|}{ Policy variables } \\
\hline Spending per pupil (SEK) & 98110 & 10305 & 0.138 & 1.437 & 0.079 \\
\hline Pupils per teacher & 11.614 & 2.319 & 0.000 & -0.050 & -0.003 \\
\hline Share of certified teachers (\%) & 69.771 & 19.996 & 0.108 & 2.209 & 0.121 \\
\hline Adaptation to student needs & 6.779 & 0.525 & 0.056 & 3.122 & 0.171 \\
\hline \multicolumn{6}{|l|}{ Socio-economic variables } \\
\hline Share of new immigrants (\%) & 11.334 & 8.396 & -0.422 & -2.711 & -0.148 \\
\hline Share of boys (\%) & 53.842 & 8.786 & -0.144 & -1.295 & -0.071 \\
\hline Parent education level (index) ${ }^{2}$ & 1.997 & 0.143 & 0.479 & 11.152 & 0.610 \\
\hline \multicolumn{6}{|l|}{ School-type } \\
\hline For-profit & 0.056 & 0.230 & -0.052 & -2.058 & -0.113 \\
\hline Non-profit & 0.006 & 0.078 & 0.178 & 3.265 & 0.178 \\
\hline
\end{tabular}


Municipality

\begin{tabular}{|c|c|c|c|c|c|}
\hline Stockholm & 0.298 & 0.458 & 0.001 & 0.032 & 0.002 \\
\hline Gothenburg & 0.071 & 0.256 & 0.005 & 0.167 & 0.009 \\
\hline Malmö & 0.140 & 0.348 & 0.007 & 0.225 & 0.012 \\
\hline
\end{tabular}

Competition of schools

$\begin{array}{llllll}\text { Distance } & 0.193 & 0.480 & -0.028 & -2.800 & -0.153\end{array}$

Top quartile

Mathematics test score $\quad 13.429 \quad 1.574$

Policy variables

$\begin{array}{lccccc}\text { Spending per pupil (SEK) } & 97420 & 10936 & 0.058 & 0.606 & 0.033 \\ \text { Pupils per teacher } & 13.609 & 2.334 & 0.002 & 0.540 & 0.030 \\ \text { Share of certified teachers (\%) } & 75.479 & 20.715 & 0.021 & 0.427 & 0.023 \\ \text { Adaptation to student needs } & 7.161 & 0.560 & 0.035 & 1.928 & 0.105\end{array}$

Socio-economic variables

Share of new immigrants (\%)

Share of boys (\%)

1.053

2.340

$-0.254$

$-1.632$

$-0.089$

Parent education level (index) ${ }^{2}$

49.135

9.307

$-0.050$

$-0.449$

$-0.025$

2.563

0.115

0.392

9.126

0.499

School-type

\begin{tabular}{|c|c|c|c|c|c|}
\hline For-profit & 0.375 & 0.484 & -0.012 & -0.472 & -0.026 \\
\hline Non-profit & 0.101 & 0.301 & 0.007 & 0.128 & 0.007 \\
\hline \multicolumn{6}{|l|}{ Municipality } \\
\hline Stockholm & 0.361 & 0.480 & 0.081 & 3.653 & 0.200 \\
\hline Gothenburg & 0.173 & 0.378 & 0.041 & 1.361 & 0.074 \\
\hline Malmö & 0.161 & 0.368 & 0.053 & 1.820 & 0.099 \\
\hline
\end{tabular}

Competition of schools

Distance

0.496

1.282

$-0.002$

$-0.209$

$-0.011$

1. Elasticity for expenditure per pupil. These estimates are from equations 1 in Table A.1.12 and 1 and 2 in

Table A.1.13.

2. Education level is based on both parents highest educational attainment and runs from 1 to 3 . 
Annex Table 17. Cross-sectional stochastic frontier analysis

\begin{tabular}{|c|c|c|c|c|c|}
\hline Dependent variable & \multicolumn{5}{|c|}{ Mathematics test scores } \\
\hline Distribution & \multicolumn{2}{|c|}{ Exponential } & & & \\
\hline Year & 2013 & 2014 & 2015 & 2016 & 2017 \\
\hline \multicolumn{6}{|l|}{ Policy variables } \\
\hline Spending per pupil & 0.020 & 0.055 & 0.082 & 0.049 & $0.102^{*}$ \\
\hline Pupils per teacher & -0.002 & -0.001 & -0.000 & -0.002 & -0.003 \\
\hline Share of certified teachers & 0.018 & 0.022 & $0.056^{* * *}$ & 0.005 & $0.075^{\star * *}$ \\
\hline Adaptation to student needs & $0.031^{* \star *}$ & $0.040^{\star \star \star}$ & $0.048^{\star \star *}$ & $0.038^{\star \star *}$ & $0.053^{\star * *}$ \\
\hline \multicolumn{6}{|l|}{ School type } \\
\hline For-profit & -0.005 & 0.001 & 0.007 & -0.005 & -0.013 \\
\hline Non-profit & 0.001 & 0.024 & -0.004 & 0.010 & 0.031 \\
\hline \multicolumn{6}{|l|}{ Socio-economic variables } \\
\hline Share of new immigrants & -0.163 & $-0.263^{* * *}$ & $-0.371^{* * *}$ & $-0.196^{* * *}$ & $-0.257^{\star * *}$ \\
\hline Share of boys & -0.050 & $-0.075^{*}$ & -0.026 & -0.041 & $-0.090^{*}$ \\
\hline Parents' education & $0.382^{* * *}$ & $0.410^{* * *}$ & $0.432^{\star * *}$ & $0.316^{* * *}$ & $0.448^{* * *}$ \\
\hline \multicolumn{6}{|l|}{ Municipality } \\
\hline Stockholm & $0.047^{\star * *}$ & $0.044^{* * *}$ & $0.043^{* * *}$ & $0.038^{* \star *}$ & $0.079^{* \star *}$ \\
\hline Gothenburg & $0.022^{*}$ & 0.018 & 0.014 & 0.013 & $0.044^{\star \star *}$ \\
\hline Malmö & $0.039^{* * *}$ & $0.041^{* * *}$ & $0.042^{* * *}$ & $0.021^{* *}$ & $0.043^{* * *}$ \\
\hline
\end{tabular}

\section{Competition}

\begin{tabular}{|c|c|c|c|c|c|}
\hline Density & -0.001 & -0.006 & -0.001 & 0.001 & -0.002 \\
\hline Constant & $1.302^{\star *}$ & 0.715 & 0.206 & $1.059^{\star \star *}$ & -0.075 \\
\hline Lambda $^{1}$ & $1.401^{* * *}$ & $1.061^{* * *}$ & $1.202^{* * *}$ & $1.127^{\star \star *}$ & $1.235^{\star * *}$ \\
\hline Average inefficiency (\%) & 9.1 & 8.4 & 11.5 & 6.9 & 10.8 \\
\hline \multicolumn{6}{|l|}{ Sample } \\
\hline Observations & 850 & 930 & 992 & 1050 & 1056 \\
\hline
\end{tabular}

$* * * * *$ and $*$ indicate significance at respectively the $1 \%, 5 \%$ and $10 \%$ level. Robust standard errors (clustered) are used.

1. Lambda is the ratio of the variances of the asymmetric and symmetric errors. 


\section{Annex B. Instrumental variable regressions}

The share of certified teachers may be endogenous, if schools achieving good results attract more certified teachers. Similarly, spending per pupil may be endogenous, if additional funding is allocated to improve the results of poorly performing schools. To test these assumptions, appropriate instruments for these variables need to be found. These instruments should be correlated with the potentially endogenous regressors, but not with the error term of the test score equation.

The proportion of female teachers is correlated with the proportion of certified teachers, but is unlikely to be correlated with test scores. ${ }^{13}$ The proportion of female teachers in the first stage regression is significant at the $1 \%$ level and the test of excluded instruments clearly rejects the hypothesis of weak instrument (Annex Table 18, column 1). According to the Anderson-Rubin Wald test, the coefficient of the share of certified teachers in the test score equation is zero and orthogonality conditions are valid. In other words, when endogeneity is accounted for, the share of certified teachers has no impact on test scores. A robustness check is carried out with both the proportion of female teachers and unemployment of teachers by municipality ${ }^{14}$ (scaled by the population of the municipality, as relevant data on labour force are not available), interpreted as a proxy for the supply of certified teachers (column 3 ). The additional variable has the right sign and is significant at the $1 \%$ level. The Sargan-Hansen test accepts over-identifying restrictions. The Anderson-Rubin Wald test does not reject the hypothesis that the coefficient of the share of certified teachers in the test score equation is zero and orthogonality conditions are valid. The coefficient of the share of certified teachers in the second stage equation is also insignificant (column 4). Hence, the results suggest an insignificant impact of the share of certified teachers on test scores, when endogeneity is accounted for.

The instrument used for spending per pupil is the young age dependency ratio by municipality. The dependency ratio is unlikely to be affected by school results. It is assumed to act as a budget constraint, ${ }^{15}$ and hence be negatively correlated with spending per pupil. Its coefficient is negative and significant at the $1 \%$ level and the test of excluded instruments clearly rejects the hypothesis of weak instrument (column 5). The AndersonRubin Wald test indicates that when endogeneity is taken into account, spending per pupil has no impact on test scores.

\footnotetext{
${ }^{13}$ Some authors have argued that teacher gender could influence student test scores. However, a recent literature review suggests such effect is absent, at least in European countries (Coenen et al., 2018).

${ }^{14}$ Graciously provided by the Swedish Public Employment Service (Arbetsförmedlingen).

${ }^{15}$ Swedish schools are mainly financed out of the municipal budget.
} 
Annex Table 18. Instrumental variable regressions

\begin{tabular}{|c|c|c|c|c|c|c|}
\hline Dependent variable & Mathematics test & & & & & \\
\hline Model & Random effects & & & & & \\
\hline Endogenous regressor & \multicolumn{4}{|c|}{ Share of certified teachers } & \multicolumn{2}{|c|}{ Spending per pupil } \\
\hline Model type & First stage & Second stage & First stage & Second stage & First stage & Second stage \\
\hline & [1] & [2] & [3] & [4] & [5] & [6] \\
\hline \multicolumn{7}{|l|}{ Instruments } \\
\hline Share of female teachers & $0.207^{* * *}$ & & $0.209^{* * *}$ & & & \\
\hline Unemployed teachers & & & $1.338^{* * *}$ & & & \\
\hline Young age dependency ratio & & & & & $-1.092^{* * *}$ & \\
\hline \multicolumn{7}{|l|}{ Tax rate } \\
\hline \multicolumn{7}{|l|}{ Policy variables } \\
\hline Spending per pupil & 0.036 & $0.101^{* * *}$ & 0.043 & $0.101^{* * *}$ & .. & 0.006 \\
\hline Pupils per teacher & 0.000 & -0.000 & 0.001 & 0.000 & $-0.004^{* * *}$ & -0.001 \\
\hline Share of certified teachers & .. & -0.131 & .. & -0.193 & 0.004 & $0.064^{* * *}$ \\
\hline Adaptation to student needs & $0.024^{* *}$ & $0.055^{\star * *}$ & $0.026^{* * *}$ & $0.058^{* * *}$ & -0.005 & $0.048^{* * *}$ \\
\hline \multicolumn{7}{|l|}{ School type } \\
\hline For-profit & $-0.099^{* * *}$ & $-0.050^{* * *}$ & $-0.097^{\star * *}$ & $-0.056^{\star * *}$ & $0.008^{* * *}$ & $-0.028^{* * *}$ \\
\hline Non-profit & $-0.076^{* * *}$ & -0.010 & $-0.062^{\star *}$ & -0.011 & -0.000 & 0.002 \\
\hline \multicolumn{7}{|l|}{ Year } \\
\hline 2014 & -0.003 & $-0.072^{* * *}$ & -0.004 & $-0.072^{\star \star *}$ & $0.031^{* * *}$ & $-0.069^{* * *}$ \\
\hline 2015 & $-0.054^{* * *}$ & $-0.141^{* * *}$ & $-0.055^{\star * *}$ & $-0.145^{\star * *}$ & $0.061^{* * *}$ & $-0.125^{\star * *}$ \\
\hline 2016 & $0.045^{\star * *}$ & -0.004 & $0.048^{* * *}$ & -0.002 & $0.099^{\star * *}$ & -0.007 \\
\hline 2017 & $0.034^{* * *}$ & $-0.129^{\star * *}$ & $0.038^{* * *}$ & $-0.125^{\star * *}$ & $0.160^{\star * *}$ & $-0.123^{* *}$ \\
\hline \multicolumn{7}{|l|}{ Socio-economic variables } \\
\hline Share of new immigrants & $-0.141^{* *}$ & $-0.338^{* * *}$ & $-0.133^{\star *}$ & $-0.343^{* * *}$ & $0.038^{* *}$ & $-0.309^{* * *}$ \\
\hline Share of boys & 0.020 & $-0.056^{\star *}$ & 0.026 & $-0.055^{\star *}$ & 0.010 & $-0.060^{* *}$ \\
\hline Parents' education & $0.100^{* * *}$ & $0.469^{* * *}$ & $0.096^{* * *}$ & $0.474^{* * *}$ & 0.013 & $0.468^{* * *}$ \\
\hline \multicolumn{7}{|l|}{ Municipality } \\
\hline Stockholm & $-0.083^{* * *}$ & $0.034^{* * *}$ & $-0.074^{* * *}$ & $0.031^{* *}$ & $0.064^{* * *}$ & $0.051^{* * *}$ \\
\hline Gothenburg & -0.017 & $0.022^{* *}$ & -0.008 & $0.025^{\star * *}$ & $0.039 * * *$ & $0.024^{* * *}$ \\
\hline Malmö & $-0.032^{* *}$ & $0.029^{* * *}$ & $-0.032^{*}$ & $0.031^{* * *}$ & $0.008^{* *}$ & $0.032^{* * *}$ \\
\hline \multicolumn{7}{|l|}{ Competition } \\
\hline Density & 0.006 & -0.005 & 0.004 & -0.004 & $0.021^{\star \star \star}$ & -0.003 \\
\hline Constant & -0.199 & 0.032 & -0.312 & 0.037 & $11.700^{* * *}$ & 1.023 \\
\hline \multicolumn{7}{|l|}{$\mathbf{R}^{2}$} \\
\hline Overall & & 0.488 & & 0.472 & & 0.521 \\
\hline Within & & 0.254 & & 0.234 & & 0.284 \\
\hline Between & & 0.566 & & 0.551 & & 0.599 \\
\hline F-test of excluded instruments ${ }^{1}$ & $26.64^{\star \star *}$ & & $15.74^{* * *}$ & & $181.84^{* * *}$ & \\
\hline Anderson-Rubin Wald test² & 1.00 & & 2.03 & & 0.00 & \\
\hline Sargan-Hansen test ${ }^{3}$ & .. & & 1.154 & & .. & \\
\hline \multicolumn{7}{|l|}{ Sample } \\
\hline Observations & 4878 & 4878 & 4878 & 4878 & 4878 & 4878 \\
\hline Schools & 1140 & 1140 & 1140 & 1140 & 1140 & 1140 \\
\hline
\end{tabular}

$* * *, * *$ and $*$ indicate rejection of the null hypothesis at respectively the $1 \%, 5 \%$ and $10 \%$ level. Robust standard errors (clustered) are used.

1. Under the null hypothesis, instruments are weak.

2. Under the null hypothesis, the coefficient of the endogenous regressor in the main equation is nil and orthogonality conditions are valid.

3. Under the null hypothesis, over-identifying restrictions are valid. 